\title{
PERSPECTIVE
}

\section{Role of vascular permeability factor/vascular endothelial growth factor in eye disease}

\author{
Reinier O Schlingemann, Victor W M van Hinsbergh
}

The eye contains highly vascularised and completely avascular tissues in close apposition. This specialised anatomy requires tight regulation of the balance between vascular quiescence and vascular growth. Growth normally occurs in ocular embryonic development, but is virtually absent from the eye in adult life. ${ }^{1}$ In eye diseases associated with angiogenesis, this delicate balance is disturbed. ${ }^{1-6}$ Angiogenesis plays a crucial role in disorders responsible for most blind registration in the Western world - that is, diabetic retinopathy (DR), retinopathy of prematurity (ROP), age-related macular degeneration (AMD), and a large number of other eye conditions. ${ }^{15}$ Because of its importance in wound healing, tumour growth, and other pathological situations, angiogenesis has been extensively studied in the fields of oncology, rheumatology, cardiology, and ophthalmology. ${ }^{78}$ The main interest in these efforts has been the notion that inhibiting angiogenesis may influence the course of tumour growth or other disease. ${ }^{910}$ In ophthalmology, inhibition of angiogenesis may also prove to be of great value. ${ }^{14-69}$

Angiogenesis is a tightly controlled process which involves both endothelial cells and pericytes, and is influenced by numerous agonist growth factors, inhibiting factors, and extracellular matrix proteins. ${ }^{711-14}$ Its importance in embryonic retinal vascularisation and eye disease (Fig 1) has long been recognised, and it was as early as 1948 that Michaelson suggested that it is the avascular fetal retina itself that produces a diffusible 'biochemical factor' capable of inducing vascular ingrowth, the production of which is associated with retinal metabolism. ${ }^{15}$ Later, when the association of neovascularisation with retinal non-perfusion and ischaemia in pathological conditions such as diabetic retinopathy was recognised, Ashton and colleagues suggested that hypoxia may be the impetus for the production of this presumed factor. ${ }^{16}{ }^{17}$

In recent years, an important candidate for Michaelson's 'factor' has emerged: vascular permeability factor or vascular endothelial growth factor (VPF/VEGF). ${ }^{48-21}$

Here we aim to describe exciting evidence pointing to the role this growth factor may play in eye disease. The understanding of the mechanisms of ocular angiogenesis derived from this work may lead to new therapeutic options for many common eye conditions.

\section{VEGF is a major angiogenesis and vascular permeability factor \\ DISCOVERY OF VPF/VEGF}

In 1982 the name vascular endothelial growth factor was first used to denote endothelium specific mitogenic activity isolated from calf retina. ${ }^{22}$ Although this growth factor had similarities with the molecule presently known as $\mathrm{VPF} /$ VEGF, it was incompletely characterised. $.^{22}{ }^{23} \mathrm{VPF} / \mathrm{VEGF}$ was isolated in 1983 by Senger et al as the result of a search

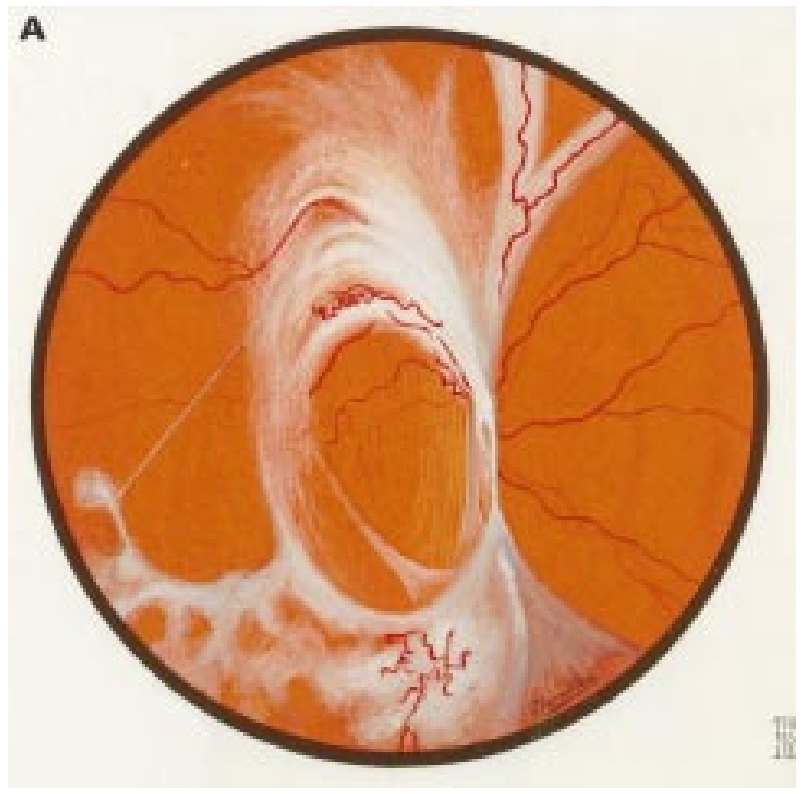

Figure 1 Early clinical observations established the importance of angiogenesis in eye disease: 'Retinitis proliferans' (proliferative retinopathy) in an 18-year-old female ( $A$ ) and 'New vessels in vitreous', associated with retinal haemorrhages (B), as painted in 1929. From the archives of Moorfields Eye Hospital.

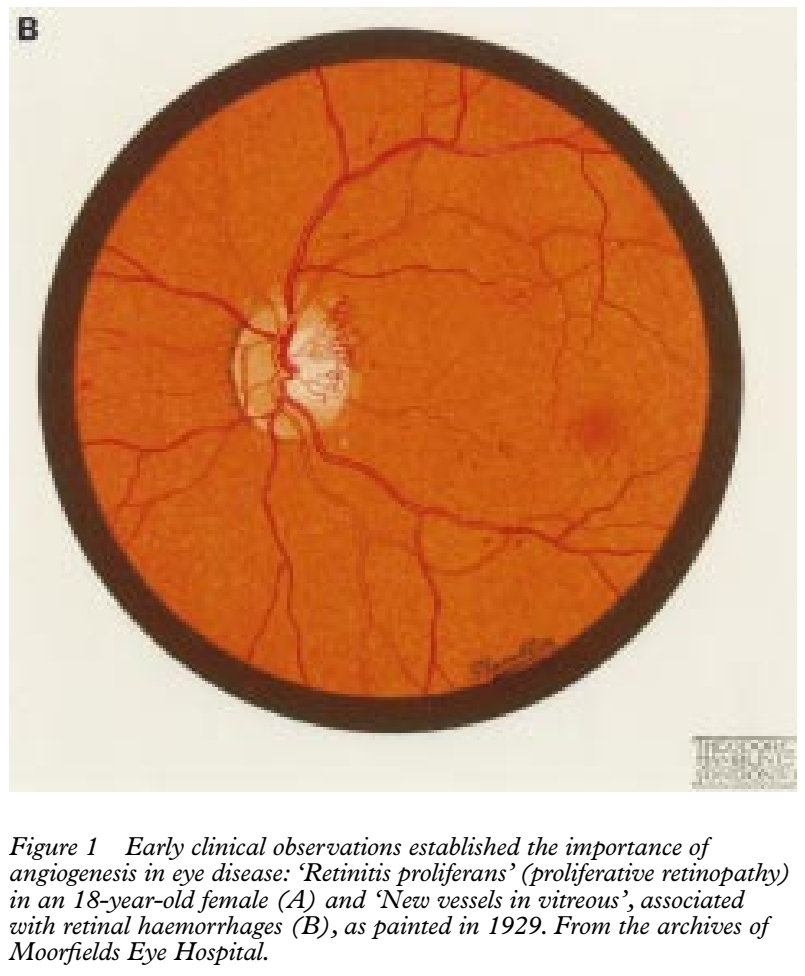



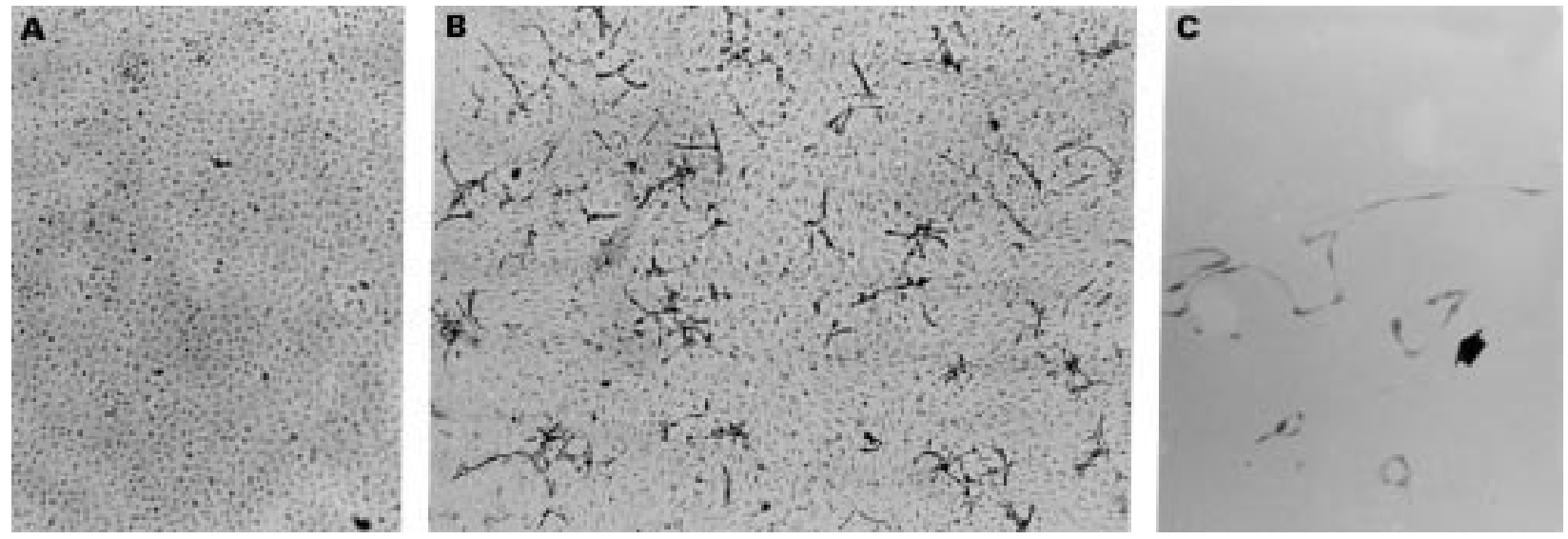

Figure 2 Formation of capillary-like tubular structures by cultured human microvascular endothelial cells in a three dimensional fibrin matrix is induced by simultaneous addition of growth factors VEGF and bFGF and the cytokine TNFa. (A) and (B) Phase contrast photomicrograph of control cells (A) and stimulated cells $(B)$ (magnification $\times 30)$; (C) cross section through the top of the fibrin layer. Endothelial cells are visible on top of the fibrin and around lumina within the fibrin matrix (arrow) ( $\times 340)$. (Courtesy Drs M Kroon and P Koolwijk.)

for tumour derived factors causing increased microvascular permeability. ${ }^{24}$ These authors hypothesised that angiogenesis in tumours and healing wounds depends on a common pathway that involves the deposition of fibrin and other extravasated macromolecules in the stroma, rather than being initiated directly by angiogenetic factors. ${ }^{24-26}$ The isolation of a tumour derived diffusible molecule enhancing this extravasation supported their hypothesis, hence the early name vascular permeability factor (VPF) ${ }^{24}$ It took 6 years to recognise that this molecule, apart from its effect on microvascular permeability, effectively had all the properties of a true angiogenesis factor. ${ }^{27}{ }^{28}$ This coincided with the isolation and subsequent cloning of two 'new' endothelial mitogens named vascular endothelial growth factor (VEGF) and vasculotropin ${ }^{29-33}$ which in the following years were recognised to be identical to VPF. ${ }^{29} 3435$ In this review we will adhere to the most commonly used designation for this factor: VEGF.

BIOCHEMICAL PROPERTIES

VEGF is a glycoprotein dimer of $34-45 \mathrm{kDa}$ with some structural homology to platelet derived growth factor (PDGF), and close homology with placenta growth factor $^{18}{ }^{36-40}$ and two other gene products, VEGF-B ${ }^{41}$ and VEGF-C. ${ }^{42}{ }^{43}$ VEGF is a secreted factor in contrast with certain other highly angiogenic cytokines, such as acidic and basic fibroblast growth factor (aFGF, bFGF). ${ }^{114446}$ Many different cell types, including endothelial cells, produce VEGF in vitro. ${ }^{47-49}$ Four different isoforms of VEGF (with 206, 189, 165, and 121 amino acids) arise from the same gene by alternative splicing. ${ }^{25} 50$ The isoforms appear to have identical biological activity but differ in molecular weight and affinity for heparin which may affect their bioavailability in tissues. ${ }^{51-53}$ Thus, the 121 and the predominant 165 species are soluble factors while the larger forms with higher heparin affinity are cell or extracellular matrix associated..$^{53}$ Enzymatic cleavage of these larger forms by plasmin can lead to the release of active diffusible VEGF and this may provide one mechanism by which VEGF activity is regulated in vivo. ${ }^{534}$

IN VIVO AND IN VITRO ACTIVITIES RELATED TO ANGIOGENESIS In vivo, VEGF potently increases microvascular permeability of post capillary venules and capillaries, ${ }^{24556}$ and can rapidly induce fenestrations in continuous endothelia when injected in skin or muscle. ${ }^{57}$ This effect on endothelial permeability is probably involved in the pathogenesis of malignant ascites, ${ }^{58}$ ovarian hyperstimulation syndrome, ${ }^{59}$ oedema around brain tumours, ${ }^{60}{ }^{61}$ bullous skin diseases, and psoriasis. ${ }^{62} 63$
The extravasation of plasma proteins caused by VEGF may be a crucial step in the neovascular response. ${ }^{12}$ However, VEGF has a number of other biological activities consistent with a role as a direct angiogenesis factor: it induces neovascularisation in several in vivo angiogenesis assays. ${ }^{1827286465}$ It is mitogenic for cultured vascular and lymphatic endothelial cells ${ }^{27} 5666$ and stimulates their migration and tube formation, the so called 'angiogenesis in vitro' (Fig 2) ${ }^{67}{ }^{68}$ It also enhances endothelial glucose transport, ${ }^{69}$ and induces expression of interstitial collagenase, the urokinase-type and tissue-type plasminogen activators and the urokinase receptor in these cells. ${ }^{70-72}$ Collagenases and plasminogen activators are proteases that enable migration of endothelial cells through the interstitium or a fibrinous exudate during angiogenesis. ${ }^{70-72}$ In addition, VEGF induces the expression of $\alpha_{\mathrm{v}} \beta_{3}$ integrin and osteopontin, ${ }^{44}$ proteins involved in cell-matrix interaction and angiogenesis. ${ }^{73-75}$ In conclusion, VEGF is able to stimulate all major functions of endothelial cells needed in angiogenesis - increased permeability, migration, proliferation, and tube formation.

THE VEGF RECEPTORS

Two high affinity receptors for VEGF, named VEGFR-1 or Flt-1 and VEGFR-2 or KDR (Flk-1 in mouse) ${ }^{35}$ 76-80 have been characterised. They are both transmembrane proteins with cytoplasmic tyrosine kinase domains, ${ }^{80}$ and are expressed on endothelial cells, including retinal endothelial cells. ${ }^{81}$ The two receptors appear to mediate different biological effects of VEGF. ${ }^{80}$

VEGF receptors are upregulated in vivo in the microvasculature in conditions with overexpression of VEGF. ${ }^{19}{ }^{63} 82-87$ In vitro, hypoxia can induce endothelial VEGF receptor expression, possibly by a paracrine mechanism. ${ }^{88}$ In cultured retinal endothelial cells, hypoxia initially downregulates VEGFR-2/KDR via adenosine and the adenosine A2 receptor, while chronic hypoxia leads to increased VEGFR-2 expression. ${ }^{81}$ On the other hand, transforming growth factor $\beta$ downregulates the expression of the VEGFR-2 in cultured endothelial cells. ${ }^{89}$

The VEGF receptors and specifically VEGFR-1/Flt-1 have been demonstrated in many other cell types, including retinal glia, retinal pigment epithelial cells, monocytes, mast cells, corneal endothelial cells, and cultured pericytes. ${ }^{190-103}$ In most of these cell types, the growth factor stimulates migration through binding to VEGFR-1/Flt-1, but not proliferation.. 929799100 Thus, VEGF may help to recruit pericytes, mast cells, monocytes, and other cells during angiogenesis or inflammation. 
The mitogenic effect of VEGF, which is mediated in cultured endothelial cells through binding to the VEGFR$2 / \mathrm{KDR}$ receptor, is restricted to endothelial cells in vivo and to endothelial cells, bovine retinal pericytes, ${ }^{98}$ and some epithelial cell types in vitro, including retinal pigment epithelial cells. ${ }^{101-103}$

ROLE OF VEGF AND ITS RECEPTORS IN EMBRYONAL DEVELOPMENT

Recent evidence shows that VEGF plays a major role in the development of the vascular system in embryogenesis. ${ }^{8}{ }^{104-107}$ In early embryos, VEGFR-2 is expressed in mesodermal cells giving rise to angioblasts, and in later stages both VEGF and its two receptors are highly expressed in a distribution suggesting a paracrine mechanism of vascular development induction. ${ }^{18}{ }^{108-110}$ For example, in the development of brain and retina, expression of VEGF correlates temporally and spatially with the ingrowth of capillaries, consistent with Michaelson's hypothesis of a retina derived factor. ${ }^{15} 104106$ In the developing retina, VEGF may also act as a survival factor for endothelium. ${ }^{111} 112$ The two VEGF receptors appear to mediate distinct functions in this process as mutations in the two receptor genes show differential lethal developmental abnormalities in transgenic mice. ${ }^{113}{ }^{114}$ Mice lacking functional VEGFR-2/KDR fail to develop blood islands and show no blood vessel development, ${ }^{113}$ while embryos deficient in VEGFR-1/Flt-1 form endothelial cells with normal differentiation but abnormal assembly of the cells in disorganised blood vessels. ${ }^{114}$ This may be consistent with a role of VEGFR-2 in mediating a mitogenic/ differentiation response of VEGF on embryonic endothelial cells and an effect on migration of vascular cells via VEGFR-1.

Mice embryos lacking one allele encoding for VEGF also have abnormal vascular development and die in utero, suggesting a tight dose dependent regulation of embryonic vascular development by VEGF. ${ }^{115} 116$

\section{INTERACTIONS WITH OTHER GROWTH FACTORS}

Other growth factors and cytokines can also potently induce or inhibit angiogenesis. ${ }^{7-1344} 46$ The interactions and stimulatory and inhibitory actions of these factors on cells in vitro and in vivo vary in different conditions and tissues. $^{4668117118}$ For example, whereas VEGF alone induces capillary-like tubular structures of bovine endothelial cells in a fibrin matrix in vitro, ${ }^{67}$ it requires the simultaneous presence of tumour necrosis factor $\alpha$ $(\mathrm{TNF}-\alpha)$ to induce human microvascular endothelial cells to form such structures (Fig 2) ${ }^{68}$ Both in vitro and in vivo, VEGF and bFGF synergistically enhance angiogenesis. ${ }^{12} 6768$ 119-121 Furthermore, many growth factors/cytokines can affect angiogenesis and microvascular permeability indirectly through the upregulation of VEGF. ${ }^{12}$ In vitro, bFGF, EGF, IGF-1, PGE ${ }_{2}, \mathrm{TNF}^{-\alpha}$, PDGF-BB, angiotensin II, and TGF- $\beta$ all upregulate VEGF expression in different cell types-for example, smooth muscle cells and fibroblasts. ${ }^{11}{ }^{12} 122-129$

From all these observations the notion has derived that the actions of a specific cytokine are contextual, ${ }^{12}{ }^{118}$ in that they are dependent on the presence of other growth factors and inhibitors, extracellular matrix composition, and expression of specific receptors on the target cells. ${ }^{72} 1346130$

HOUSEKEEPING FUNCTIONS OF VEGF IN NORMAL ADULT TISSUES

It is important to realise that the functions of VEGF are not limited to angiogenesis, wound healing, and embryogenesis. ${ }^{8}$ VEGF messenger RNA has been demonstrated in many normal adult tissues without angiogenesis, in mouse, rat, and humans, with highest levels in lung, liver, kidney, heart, and adrenal gland. ${ }^{106131-133}$ This suggests unknown housekeeping functions of the cytokine. $^{106131-133}$ Based on expression of VEGF in glomeruli and collecting duct epithelium of the kidney, ${ }^{108134135}$ and its receptors in endothelium and mesangial cells of the glomerulus, ${ }^{95}$ it was proposed that the factor may induce baseline vascular permeability and/or the fenestrated endothelial phenotype..$^{95108} 134135$ In liver and choroid plexus in the brain a similar mechanism may occur. ${ }^{106}{ }^{136}$ The observation that exogenous VEGF can rapidly induce fenestrations in the continuous endothelium of skin and muscle in vivo seems to support this hypothesis. ${ }^{57}$ Other suggested functions of VEGF, which act via endothelial cell stimulation, are in the response of cardiac and skeletal muscle to stimulation and hypoxia, ${ }^{137-141}$ coronary artery relaxation, ${ }^{142}$ and pancreatic islet maintenance. ${ }^{91}{ }^{143}$ It may also act as an epithelial mitogen in hair formation. ${ }^{102}$ Furthermore, VEGF plays a role in monocyte migration ${ }^{92}{ }^{97}$ and haematopoiesis, possibly as a survival factor for certain haematopoietic cells, including leukaemia cell lines. ${ }^{93} 144$

\section{Role of VEGF in hypoxia induced angiogenesis}

ROLE OF VEGF IN PHYSIOLOGICAL AND PATHOLOGICAL ANGIOGENESIS

VEGF and its receptors are overexpressed in many tissues with blood vessel growth, often together with other angiogenesis factors. ${ }^{12} 196382-86107145146$ Angiogenesis in the cycle of the female reproductive organs correlates with VEGF expression, ${ }^{147-150}$ and is possibly under hormonal control. ${ }^{147}{ }^{149}$ Angiogenesis is also associated with upregulation of VEGF messenger RNA in tissue responses to injury, such as wound healing ${ }^{86}$ and formation of collateral vascularisation in cardiac ischaemia, ${ }^{139-141}$ and in pathological angiogenesis in solid tumour growth, ${ }^{19} 458285133145$ rheumatoid arthritis, ${ }^{151}$ psoriasis, ${ }^{63}$ capillary haemangiomas, ${ }^{152}{ }^{153}$ and atherosclerosis. ${ }^{154}$

In many human and experimental tumours VEGF expression correlates with tumour vascularity, tumour progression, and metastatic potential. ${ }^{83}{ }^{845-158}$ The marked effect on the growth of certain experimental tumours in vivo by inhibition of VEGF by neutralising antibodies ${ }^{159-161}$ or transfection of antisense VEGF cDNA, ${ }^{162}$ and by inhibition of its receptors by transfection of a dominant negative VEGFR-1/Flk-1 mutation ${ }^{163} 164$ further underscores the importance of this growth factor in tumour angiogenesis. Therapeutic inhibition of VEGF may therefore prove a valuable new treatment modality in cancer patients.

VEGF IS UPREGULATED BY HYPOXIA IN VITRO AND IN VIVO In 1992, Shweiki et al showed that VEGF messenger RNA was mainly expressed in the vicinity of necrotic and presumably hypoxic foci in glioblastoma multiforme and they demonstrated that hypoxia upregulated VEGF expression in glioma cells in vitro. ${ }^{145}$ Since then other tumour cells, ${ }^{165166}$ vascular smooth muscle cells, ${ }^{122} 123126$ pericytes, ${ }^{167}{ }^{168}$ retinal pigment epithelial cells, ${ }^{167}$ and endothelial cells ${ }^{96167-170}$ were found to have de novo (endothelial cells), or upregulated (other cell types) expression of VEGF when grown under hypoxic conditions. ${ }^{171}$ In vascular smooth muscle cells this effect is synergistically enhanced by bFGF or PDGF-BB. ${ }^{123}{ }^{126}$ In multicell spheroids of glioma cultured in vitro, VEGF expression is found in the inner hypoxic cells. ${ }^{172-174}$

It is not entirely clear how hypoxia upregulates VEGF at the molecular level. ${ }^{173}{ }^{175}$ This appears to be partly due to transcriptional activation of the VEGF gene, in a manner similar to hypoxia induced erythropoietin gene expression, ${ }^{169} 1711^{176-181}$ but mostly by post-transcriptional 
stabilisation of VEGF messenger RNA. ${ }^{165} 169173$ 182-185 Furthermore, adenosine, which is released from hypoxic tissues, can upregulate VEGF expression ${ }^{166}$ through the adenosine $\mathrm{A}(2 \mathrm{a})$ receptor and the cAMP dependent protein kinase A pathway, as has been demonstrated in retinal vascular cells. ${ }^{168}$

In addition to hypoxia and low glucose, mutations in the p53 cancer suppressor gene $e^{186} 187$ and the von Hippel Lindau tumour suppressor gene, ${ }^{185}{ }^{188}$ or activation of the ras oncogene may also induce upregulation of VEGF expression in human cancer cells, providing a possible mechanism of the neoplastic progression associated with these genes. ${ }^{175}$ 185-189

\section{Does VEGF play a role in eye disease?}

OCULAR ANGIOGENESIS

Angiogenesis is crucial in the development of the eye as well as in the pathogenesis of a variety of ocular diseases. ${ }^{1-6}{ }^{104}$ Corneal neovascularisation, rubeosis of the iris, proliferative retinopathies, and subretinal neovascularisation may result from a multitude of unrelated disease states. It should be realised that in all these conditions vascular growth is part of a wound healing response which usually also involves inflammatory cells, (myo)fibroblasts, and in the posterior segment, glial cells or activated pigment epithelial cells. ${ }^{112}$ In the past three years, extensive evidence has become available that VEGF is involved in probably all forms of ocular angiogenesis. In fact, it corresponds well with the diffusible retinal vasoformative 'factor' as originally proposed by Michaelson in 1948. ${ }^{15}$ However, the available data imply that other factors also contribute to the initiation or maintenance of ocular neovascularisation.

\section{VEGF AND THE CORNEA}

Exogenous VEGF potently stimulates angiogenesis in the cornea of experimental animals with no or little inflammatory response. ${ }^{65}{ }^{190}$ However, the role of the factor in pathological corneal neovascularisation, as occurs in contact lens wearers, after corneal trauma and transplantation or in inflammatory conditions, is unclear. Recently it has been demonstrated that VEGF is produced in whole rabbit corneas kept in culture, and is upregulated in the rat cornea in vivo after 2 weeks of atmospheric hypoxia. ${ }^{191}{ }^{192}$ Epithelial cells from normal avascular cornea produce VEGF, but do so at a lower level than epithelial cells from vascularised cornea or conjunctiva. ${ }^{193}$ These preliminary data suggest some role for the factor in corneal angiogenesis. Another interesting finding is the expression of the Flt-1/VEGFR-1 and VEGF in dedifferentiated corneal endothelial cells in vitro $^{194}$ and the migration, but not proliferation, of these cells in response to $\mathrm{VEGF}^{99}$

\section{RETINAL ISCHAEMIA}

In clinical ophthalmology it is evident that diseases of the retina which are associated with impaired capillary or venous circulation can lead to retinal neovascularisation (proliferative retinopathies) (Figs 1 and 3)..$^{1-6} 104195$ Viable ischaemic retinal tissue seems to be a prerequisite for an angiogenic response in these conditions, probably through the release of an angiogenic factor by retinal cells triggered by hypoxia. ${ }^{15-17} 195196$ Oxygen measurements in experimental animals and patients indeed have shown that retinal $\mathrm{Po}_{2}$ is very low in ischaemic retinal conditions. ${ }^{6}{ }^{197}$ Surprisingly, panretinal photocoagulation, which is an effective treatment modality for proliferative retinopathies, can restore retinal $\mathrm{PO}_{2}$ levels, most probably through a decrease of outer retinal oxygen consumption and improved oxygen diffusion from the choroid. ${ }^{197}$
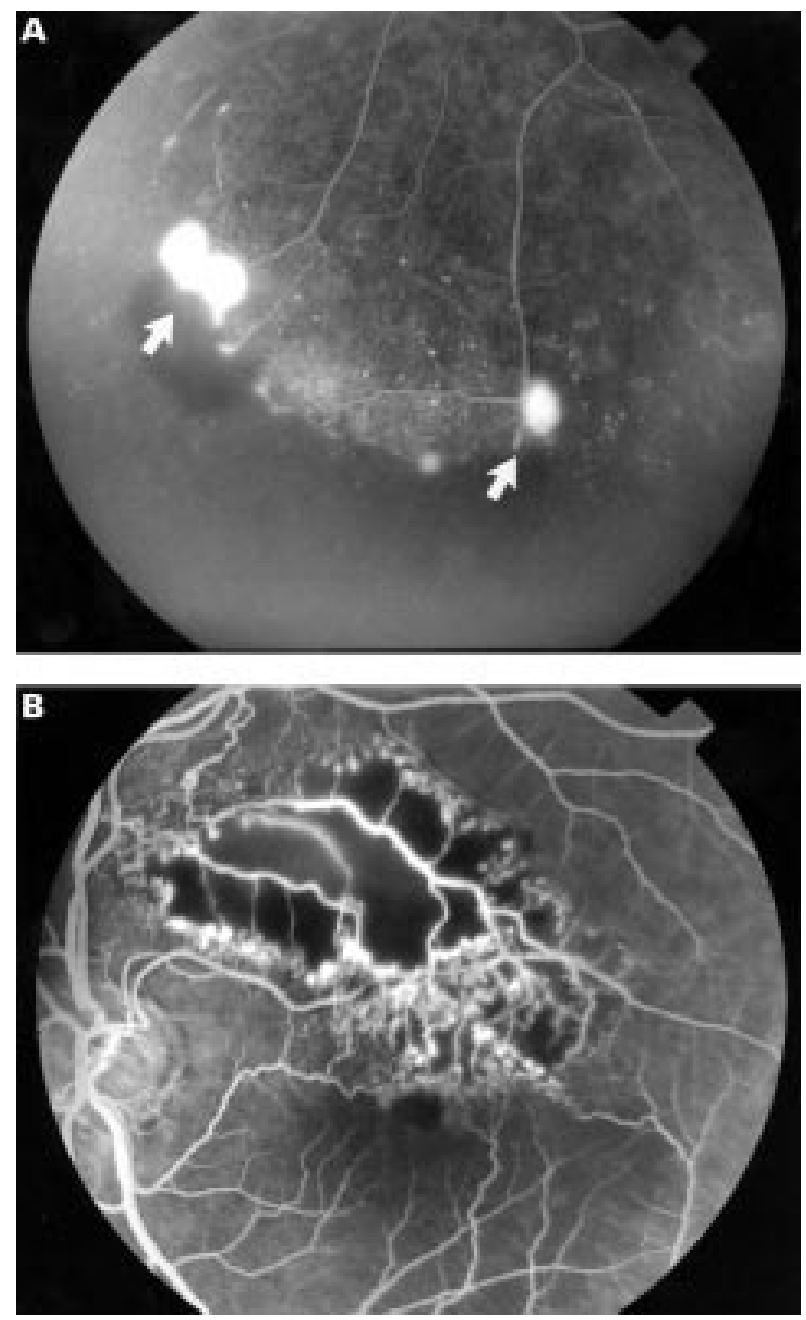

Figure 3 Retinal non-perfusion (recognisable as dark areas) in two patients with inflammatory vasculitis $(A)$ and branch retinal vein occlusion (B). Note the profuse leakage of newly formed vessels (arrows) on the edge of the peripheral retinal non-perfusion $(A)$ and the leakage of dilated vessels in and on the edge of the non-perfused area in the macular retina in (B). Experimental evidence suggests that these vascular changes may (in part) be mediated by VEGF.

Strong evidence now suggests that VEGF is a major cytokine produced by hypoxic retina. In a primate model of retinal ischaemia produced by branch vein occlusions it was shown that the resulting vascular dilatation, leakage, and endothelial proliferation in the iris temporally correlate with upregulated expression of VEGF messenger RNA in the ischaemic retina, and with elevated levels of growth factor in aqueous. ${ }^{198} \mathrm{~A}$ neutralising antibody to VEGF injected into these eyes prevented the vascular changes in the iris, but had no effect on the retinal production of the growth factor, indicating that VEGF is indeed required for the observed effect on the iris. ${ }^{199}$ In this model, scatter photocoagulation led to recovery from retinal hypoxia, and a decrease of VEGF expression in the retinal areas treated with laser. ${ }^{200}$ Comparable results have been obtained in other experimental models of retinal ischaemia in rabbits and rats. ${ }^{201} 202$ These studies suggest that VEGF plays a key role in ischaemia induced permeability and angiogenesis.

Several cell types, including ganglion cells, appear to express VEGF in the ischaemic retina in vivo. ${ }^{203}$ These findings correlate with in vitro experiments that have shown that retinal pericytes, ${ }^{167} 168$ endothelial cells, ${ }^{167168}$ and glial cells ${ }^{204-206}$ produce VEGF in response to hypoxia. ${ }^{104167168205206}$ Possible mechanisms for increased 
VEGF production in ischaemic retina in vivo are by a paracrine effect of increased levels of adenosine and by hypoxia induced VEGF messenger RNA stabilisation ${ }^{168} 182$ (see earlier).

The conclusions from the animal studies cited above are supported by recent reports showing that recombinant VEGF injected into the vitreous of monkeys is sufficient to induce vascular changes in the iris and eventually neovascularisation and neovascular glaucoma. ${ }^{207}{ }^{208}$ In the retina itself, intravitreal VEGF induces vascular leakage, hyperplasia, and the formation of microaneurysms in monkeys ${ }^{209}$ and formation of preretinal new vessels in rabbits. ${ }^{208}$ Remarkably, in these models, the presence of exogenous or upregulated endogenous VEGF is always associated with marked early effects on vascular permeability, ${ }^{210}$ but does not necessarily lead to angiogenesis. The typical preretinal neovascularisation as seen by clinicians in the posterior segment of patients appears only late in VEGF injected rabbits and not at all in monkeys. ${ }^{198} 199201208209$ These findings suggest that other factors are important and necessary to lead to true retinal neovascularisation.

This is further emphasised by recent work indicating that VEGF and its receptors may also be involved in retinal conditions that are not associated with angiogenesis or ischaemia. Expression of VEGF and both its receptors was found in cultured human RPE and glial cells at the RNA level, ${ }^{94} 101$ and immunohistochemical VEGF staining was found to be increased in situations where breakdown of the blood-retinal barrier is prominent such as experimental autoimmune uveitis in rats, human uveitis, and aphakic/ pseudophakic macular oedema. ${ }^{211}$

\section{ROLE OF VEGF IN DIABETIC RETINOPATHY AND VENOUS} OCCLUSIVE DISEASE

Diabetic retinopathy (DR) is characterised by the development of microvascular leakage and focal areas of retinal ischaemia in non-proliferative DR (NPDR), or by neovascularisation originating from the disc and peripheral retina in response to widespread retinal ischaemia (proliferative DR).

Retinal vein occlusions may also show extensive retinal non-perfusion with leakage and ischaemia (Fig 3B) leading to retinal or iris neovascularisation..$^{3212-214}$ Based on the previously described findings in animal models it is not surprising that upregulation of VEGF messenger RNA, and marked immunohistochemical microvascular staining for the factor have been demonstrated in the retinas of patients with proliferative $\mathrm{DR}$ and central retinal vein occlusions (CRVO). ${ }^{201} 215216$ Furthermore, several studies have demonstrated significantly elevated levels of VEGF in ocular fluids from patients with active diabetic proliferative disease or ischaemic CRVO compared with patients with inactive proliferative disease, after extensive laser surgery, or those with NPDR. ${ }^{217-219}$ None of the other known angiogenesis factors, except insulin-like growth factor-1 (IGF-1), ${ }^{44} 129220$ show such a strong correlation with ischaemia related ocular angiogenesis in humans. ${ }^{217-219} 221$ In addition to hypoxia, elevated glucose levels alone may also upregulate VEGF in diabetics. ${ }^{22}$ However, it is remarkable that a significant number of diabetic patients with established active neovascularisation have undetectable levels of VEGF in ocular fluids. ${ }^{217-219}$ Although this observation does not exclude the possibility that VEGF plays a primary role in the onset of retinal angiogenesis, possibly when widespread retinal ischaemia leads to a certain critical level of the growth factor in the retina or vitreous, it does indicate that other factors also can contribute to active neovascularisation in the eye.

More localised retinal expression of VEGF may only lead to increased microvascular permeability as recent work suggest that VEGF is also upregulated in NPDR and other causes of retinal oedema. ${ }^{21215223224}$ Surprisingly, increased immunohistochemical staining for VEGF could even be demonstrated in glial cells in the retina of patients with diabetes without signs of DR. ${ }^{224}$ Still, in diabetic rats, increased microvascular permeability, as demonstrated by extravasation of endogenous albumin, correlates with elevated expression of VEGF messenger RNA and immunohistochemical demonstration of the growth factor in microvessels. ${ }^{223}{ }^{225}$ Retinal microvascular leakage is a major cause of visual loss in NPDR, vein occlusions, and other conditions and the above results suggest that VEGF inhibition may be used to treat these disorders.

RUBEOSIS OF THE IRIS

Growth of leaky new blood vessels on the surface of the iris is a feared complication of uncontrolled proliferative DR, ischaemic CRVO, and tumours of the posterior segment of the eye. ${ }^{226}$ In particular, neovascularisation of the chamber angle with contraction of scar tissue may occur and lead to neovascular glaucoma and, potentially, loss of the eye. Rubeosis has long been attributed to diffusion of a vasoformative factor from ischaemic posterior segment structures. ${ }^{212}$

Recent reports indicate that VEGF corresponds well with this factor. ${ }^{218} 221$ In a series of 38 patients with iris neovascularisation $85 \%$ of the cases with active rubeosis had detectable levels of VEGF in the aqueous or vitreous fluid, against only one out of five $(20 \%)$ cases with inactive iris neovascularisation. ${ }^{218}$ This difference was statistically significant. Another study demonstrated increased microvascular immunohistochemical staining for VEGF in the iris and other ocular structures of enucleated eyes with choroidal melanoma, but did not mention a relation with rubeosis. ${ }^{227}$ Furthermore, the experimental animal models described above show a convincing relation between retinal VEGF expression induced by ischaemia and increased vascular permeability, dilatation, and endothelial proliferation in iris vessels. ${ }^{198} 199202$ However, these changes occur much earlier after onset of experimental retinal ischaemia than rubeosis occurs in ischaemic CRVO seen clinically. ${ }^{212} 214$ They have been interpreted to represent true iris neovascularisation. ${ }^{198}{ }^{199}$ However, they could just represent changes in pre-existing iris vessels, ${ }^{208}$ and as such may be quite different from the sprouting new vessels on the surface of the iris seen in clinical rubeosis.

RETINOPATHY OF PREMATURITY

Morphological studies on the mechanism of the normal development of retinal vasculature, and on the pathogenesis of retinopathy of prematurity (ROP) helped to form the concept of a hypoxia induced retinal vasoformative factor as put forward by Michaelson and Ashton. ${ }^{15-17}{ }^{196}$ In the mammalian embryo, sprouting of vessels occurs from the hyaloid vessels at the disc towards the retinal periphery, preceded by mesenchymal cells and astrocytes. ${ }^{15-17} 196$ Indeed, recent work has shown that in newborn rats and fetal kittens, early expression of VEGF by these astrocytes in the inner retina is closely followed by formation of the inner vascular network, ${ }^{104228} 229$ and that expression of the factor by Müller cells in a later stage precedes the ingrowth of blood vessels from the superficial network to the level of the inner nuclear layer and subsequent formation of the outer capillary plexus. ${ }^{104}$ This pattern led these authors to propose that hypoxia caused by the onset of neuronal activity is the stimulus for strategically located astrocytes and Müller cells to produce VEGF at different stages of development, leading to horizontal or vertical vascular ingrowth, respectively. ${ }^{104}$ When hypoxia is relieved by the new vessels, VEGF expression decreases and angiogenesis 
comes to a halt. ${ }^{104}$ This reconstruction is consistent with the concepts proposed by Michaelson and Ashton. ${ }^{15}{ }^{17}$

Retinopathy of prematurity may be the result of a distortion of these processes. ${ }^{104111196204230231}$ This disease is characterised by the obliteration of newly formed retinal vasculature, and cessation of peripheral vascular outgrowth in the premature infant as a result of hyperoxia from artificial respiration with high oxygen levels. When the child returns to breathing room air, a neovascular response follows consisting of abnormal, leaky, preretinal vessels on the edge of the avascular tissue, which may invade the vitreous and can lead to tractional retinal detachment and blindness. ${ }^{196} 230$ The role of VEGF in ROP has been extensively studied in experimental animal models of the disease. In these models, newborn rodents, pups, or kittens are first kept in hyperoxic ( $70-80 \%$ oxygen) conditions for 4-5 days, and are then returned to room air. In such a model in the rat, 2 days of hyperoxia led to downregulated expression of VEGF, and this preceded endothelial apoptosis and vascular closure. ${ }^{111}$ These vascular effects could be prevented by a single intravitreal injection of VEGF before exposure to hyperoxia. ${ }^{111}$ Similar results were obtained in an identical mouse model. ${ }^{112}$ In these models, after return of the animals to room air, VEGF was markedly upregulated in the affected retinal areas, presumably in Müller cells, before preretinal and vitreal neovascularisation occurred. ${ }^{204}$ Inhibition of VEGF in these mice significantly diminished the number of (presumed) endothelial cells in the vitreous, interpreted by these authors as a measure of retinal neovascularisation. ${ }^{232}{ }^{233}$ Surprisingly, in these rodent models vascular closure caused by hyperoxia occurs in the posterior retina, while the already fully formed peripheral vasculature remains unaffected, ${ }^{11} 204$ the reverse pattern from human ROP. In the feline model of ROP developed by Ashton, which resembles human ROP more closely, ${ }^{230}$ similar results were obtained. ${ }^{231}$ In these kittens, overexpression of VEGF in peripheral avascular retina after return to room air was apparently situated in the ganglion cell layer and associated with degeneration of the astrocytes. $^{231}$ These findings indicate that VEGF, in addition to its function as an angiogenesis factor, may also act as a survival factor for newly formed capillaries in the developing retina and suggest an important role for VEGF in the pathogenesis of human ROP. However, the inability of VEGF antagonists to completely inhibit angiogenesis in the rodent ROP models suggests that VEGF is not the only factor involved in angiogenesis in ROP. ${ }^{232} 233$

\section{RETINAL ANGIOMAS}

Retinal capillary angiomas may occur in the context of von Hippel-Lindau (VHL) disease. In VHL haemangioblastomas from the brain, which are histologically indistinguishable from the retinal angiomas, ${ }^{234}$ VEGF and its receptors were shown to be markedly upregulated..$^{152} 153$ The VHL tumour suppressor gene has been cloned and recent work suggests that the VHL protein is involved in the oxygen dependent regulation of production of VEGF, platelet derived growth factor B chain and the GLUT-1 glucose transporter at the post-transcriptional level. ${ }^{185} 188235$ Therefore, inactivation of the VHL tumour suppressor gene, as found in VHL disease, may lead to uncontrolled production of VEGF. ${ }^{185} 188235$ Though not yet demonstrated for retinal angioma, the possibility exists that this mechanism is involved in the pathogenesis of retinal angiomas in VHL disease.

CHOROIDAL NEOVASCULARISATION

Subretinal or choroidal neovascularisation (CNV) is a major complication of diseases affecting the retinal pigment epithelium (RPE)-choroid interface, most notably age-related macular degeneration (AMD). It is characterised by the growth of a fibrovascular tissue derived from the choroid. Macrophages, myofibroblasts, and transdifferentiated pigment epithelial cells accompany the growing blood vessels, leading to the formation of a fibrotic scar. Several angiogenic and other growth factors have been found in these membranes, ${ }^{11}$ and a role for VEGF in this common pathway of subretinal angiogenesis has been suggested by recent experimental data. The growth factor has been shown by immunohistochemistry in macrophages, ${ }^{236}$ transdifferentiated RPE, ${ }^{237}$ and by in situ hybridisation in fibroblasts and inflammatory cells ${ }^{238}$ in surgically removed specimens of these membranes, and in the RPE and retina of postmortem eyes of patients with age-related maculopathy with or without $\mathrm{CNV}^{224}{ }^{239}$ These observations are supported by the expression of VEGF by cultured RPE cells and choroidal fibroblasts. ${ }^{101} 240241$ Furthermore, significantly elevated levels of VEGF were found in the vitreous of patients with $\mathrm{CNV}^{242}$ How all these different observations fit together to explain the pathogenesis of $\mathrm{CNV}$ remains unclear.

POSSIBLE HOUSEKEEPING FUNCTIONS OF VEGF IN THE NORMAL EYE

As in other adult tissues, low constitutive expression of VEGF messenger RNA has been demonstrated in almost all tissues of the normal eye, most notably in the ciliary body, conjunctiva, RPE/choroid, and lens. ${ }^{111} 203243244$ In vitro, RPE cells produce VEGF, ${ }^{101} 167240245$ and in a coculture system this factor is partly responsible for enhanced choroidal endothelial tube formation induced by overlying RPE cells. ${ }^{245}$ Therefore, it has been hypothesised that RPE derived VEGF may act as a trophic factor for the choriocapillaris. ${ }^{11}{ }^{240}$ In general, however, the function of VEGF expression in the normal eye is unknown. ${ }^{243}$

\section{VEGF and its receptors as targets in ocular therapy} CLINICAL CONSIDERATIONS IN VEGF INHIBITION

Despite considerable therapeutic advances consequent upon the introduction of laser treatments, pathological angiogenesis and increased vascular permeability are still major causes of visual loss. ${ }^{46}$ Laser treatment is often unpleasant for the patient and its therapeutic effect depends on ablation of viable normal tissue, therefore leading to a loss of function. ${ }^{197}$ VEGF has been implicated in the pathogenesis of all the common conditions where laser treatment is currently used: NPDR and proliferative DR, RVO, ROP, and CNV. Inhibition of VEGF activity in these patients may prove a valuable alternative or additional therapeutic option and this could mean a major advance in ophthalmology.

From the previous paragraphs it is reasonable to conclude that VEGF plays an important and probably a pivotal role in ocular angiogenesis and increased microvascular permeability. Whether this role is mainly in initiation (directly or indirectly) or in maintenance of a neovascular response and/or vascular leakage is not known. This would have important implications for the use of VEGF inhibitory agents, as a significant number of patients still present with more or less established neovascularisation or macular oedema. Preventive neutralisation of VEGF in the experimental rodent models of $\mathrm{ROP}^{232} 233$ or in the cynomolgus monkey venous occlusion model ${ }^{199}$ has a significant inhibitory effect on preretinal neovascularisation or iris vascular changes, respectively. However, it remains to be seen how ocular VEGF inhibition will affect active or advanced neovascularisation or established oedema. 
In the past 25 years several indications for laser therapy in DR and vein occlusions have been established through carefully designed randomised clinical trials. It seems reasonable to use these indications as starting points for planning clinical trials with VEGF inhibitory agents. Initial trials should use such agents only in situations that are known not to benefit from laser or in cases that have not responded to laser therapy, as it would be unethical to deny patients the established beneficial effect of the present laser treatments. Subsequent trials may evaluate their use as adjuvants or replacements for laser therapy.

\section{THERAPEUTIC USE OF VEGF}

Therapeutic use of VEGF could also be useful in certain situations, such as in stimulating collateral formation in limb ischaemia resulting from arterial occlusion. ${ }^{246}{ }^{247} \mathrm{In}$ the developing retina VEGF appears to act as a survival factor for the microvasculature, so that exogenous VEGF may be able to prevent vascular obliteration in ROP. ${ }^{111} 112$

\section{STRATEGIES IN ANTI-VEGF THERAPY}

The actions of VEGF may be inhibited in several ways. Which of these approaches is clinically useful remains to be determined, as all are still in an experimental stage of development. Some proposed strategies interfere with the basal or hypoxia induced production of VEGF by effector cells. Others are aimed at neutralising soluble VEGF or to prevent its actions by blocking receptors or the transduction of receptor mediated intracellular pathways in target cells. Finally, VEGF induced angiogenesis may be inhibited by interference with the microvascular cellular response to the growth factor.

\section{Inhibition of VEGF production}

Antisense oligodeoxynucleotides can impair production of VEGF in effector cells at the RNA level. ${ }^{233}$ These compounds have the pharmacological advantage that they are small and highly specific. They may have the theoretical disadvantage of blocking both basal and induced VEGF expression. In the mouse model of retinopathy of prematurity, injection of these agents before the development of preretinal neovascularisation led to partial inhibition of VEGF production and preretinal angiogenesis. ${ }^{233}$

Recent work has shown that hypoxic induction of VEGF can be mediated by adenosine ${ }^{166}$ and the adenosine $\mathrm{A}(2 \mathrm{a})$ receptor, ${ }^{168}$ and this may lead to therapeutic strategies aimed to specifically inhibit hypoxia induced VEGF production. However, this approach may be complex, because the action of adenosine proceeds via cyclic AMP, and cAMP is also a physiological mediator counteracting increased endothelial permeability. ${ }^{248}$

\section{Neutralisation of free VEGF}

Free VEGF can be neutralised by specific antibodies. ${ }^{159} 199249$ Intravitreal injections with such antibodies were able to prevent iris vascular changes in the monkey model of retinal ischaemia. ${ }^{199}$ Alternatively, soluble VEGF receptor chimeric proteins may inhibit VEGF, as was shown to be effective in the mouse model of ROP. $^{232}$

\section{VEGF receptors and intracellular signal transduction pathways}

Another approach in VEGF inhibition is aimed at blockage of the VEGF tyrosine kinase receptors or their intracellular transduction pathways. ${ }^{163} 164250251$ In several experimental tumour models, transfection with a dominant negative VEGF receptor Flk-1 mutant was able to suppress tumour growth. ${ }^{163164}$
The mitogenic effect of VEGF on endothelial cells appears to be mediated by certain isoforms of protein kinase C (PKC) ${ }^{252}{ }^{253}$ and specific PKC inhibitors are able to inhibit VEGF induced endothelial proliferation and angiogenesis. ${ }^{250-253}$ However, such inhibitors are not specific for the eye, and much has to be learned about how they may affect wound healing and collateral formation.

\section{Endothelial cellular response to VEGF}

As outlined before, VEGF induces several functional changes in endothelial cells related to microvascular permeability or angiogenesis. These cellular response to the cytokine (and other angiogenesis factors) may be specifically inhibited-for example, by interfering with endothelial migration through integrin antagonists ${ }^{73-75} 254$ or inhibitors of cell associated plasminogen activation. ${ }^{72}$

\section{POTENTIAL SIDE EFFECTS OF VEGF INHIBITION}

A matter of concern in the clinical use of VEGF inhibition is the possible role of the growth factor in physiological angiogenesis and other vital functions. Wound healing, the female reproductive cycle, collateral formation in cardiac ischaemia and other tissue responses may be influenced by interfering with VEGF activity (see earlier). Furthermore, the constitutive expression of the molecule in normal quiescent ocular ${ }^{111203243244}$ and other tissues ${ }^{106} 1^{131-133135}$ suggests unknown but potentially important functions. For example, basal production of VEGF by epithelia may maintain certain capillary beds, as has been suggested for the choroid plexus and the kidney. ${ }^{106} 134135$ Retinal pigment epithelium (RPE) in culture has been shown invariably to produce VEGF. ${ }^{101} 167240245$ If a similar mechanism is operative between the RPE and the choroidal capillaries, ${ }^{240} 245$ VEGF inhibition could lead to choroidal atrophy. Therefore, both systemic and local ocular inhibition of VEGF may have serious side effects.

\section{PHARMALOGICAL ASPECTS AND DRUG DELIVERY OF VEGF} INHIBITORY AGENTS

Application of medical inhibition of ocular angiogenesis or macular oedema will present ophthalmologists with many new problems in practical clinical management. Certain conditions may require short term or long term application, possibly through new drug delivery devices. Recently, several new drug delivery systems have been developed. ${ }^{255-257}$ This technology could help to target stable VEGF inhibitors to the posterior segment. For less stable protein agents, gene therapy aimed at temporary expression of these compounds by the retinal pigment epithelium may prove useful in the future.

\section{Conclusion}

VEGF appears to play an important role as a vascular permeability and angiogenesis factor in the developing eye and in pathological eye conditions. It is amazing that the predictions of investigators like Michaelson and Ashton have been confirmed after almost 50 years. In the past few years our understanding of the molecular mechanisms of ocular angiogenesis has dramatically increased. More important, inhibitors of this growth factor may provide clinicians with powerful tools to treat the common ocular diseases in which angiogenesis or loss of the blood-retinal barrier cause visual impairment.

However, it should be realised that there is still much to be learnt about the exact role of VEGF and other angiogenesis factors, and their interactions, in pathological conditions as well as in the normal eye. ${ }^{11}$ As with other growth factors, the actions of VEGF seem to be contextual, depending upon expression of receptors, the extracellular matrix, extravasated plasma proteins, other 
cytokines and other, maybe unknown, influences. ${ }^{12}{ }^{44}$ Furthermore, the experimental animal models of ocular angiogenesis, from which we have learned most of the role of VEGF in the eye, are quite different from the human disease states, most notably in their time course and pathogenesis.

However, when all the experimental findings are taken together, VEGF has emerged as a major angiogenesis factor in the developing and adult human eye. Modulation of VEGF expression and its effect on angiogenesis and vascular permeability will give us new insights in pathological mechanisms at play in the eye. It is through these insights and by learning the interactions of VEGF with other mediators of angiogenesis that we can hope to develop new means of preventing or treating conditions which all too often lead to significant visual loss or blindness.

We would like to thank the Medical Illustration Department of Moorfields Eye Hospital for preparing the photographs and Professor A C Bird, Dr R Guymer, and Professor M D de Smet for their helpful comments. The financial support of the Rotterdamse Vereniging Blindenbelangen, the Stichting Blindenpenning, the Stichting Blindenhulp, the Praeventiefonds (grant 28-2622-3), and the Diabetes Fonds Nederland (grant 95-103) is gratefully acknowledged.

\section{REINIER O SCHLINGEMANN}

Department of Clinical Ophthalmology, Moorfields Eye Hospital, London, and Department of Ophthalmology, Academic Medical Center, Amsterdam, Netherlands

VICTOR W M VAN HINSBERGH

\section{Gaubius Laboratory TNO PG, Leiden, Netherlands}

Correspondence to: Dr R O Schlingemann, Department of Ophthalmology, Academic Medical Center, Meibergdreef 9, 1105 A2 Amsterdam, Netherlands.

1 Garner A. Ocular angiogenesis. Int Rev Exp Pathol 1986;28:249-306.

2 Henkind P. Ocular neovascularization. The Krill memorial lecture. Am $\mathcal{F}$ Ophthalmol 1978;85:287-301.

3 Ashton N. Neovascularization in ocular disease. Trans Ophthalmol Soc UK 1961;81:145-57.

4 Ferrara N. Vascular endothelial growth factor. The trigger for neovascularization in the eye. Lab Invest 1995;72:615-8.

5 Jampol LM, Ebroon DA, Goldbaum MH. Peripheral proliferative retinopathies: an update on angiogenesis, etiologies and management. Surv Ophthalmol 1994;38:519-40.

6 D'Amore PA. Mechanisms of retinal and choroidal neovascularization. Invest Ophthalmol Vis Sci 1994;35:3974-9.

7 Diaz-Flores L, Gutierrez R, Varela H. Angiogenesis: an update. Histol Histopathol 1994;9:807-43.

8 Risau W. Angiogenesis and endothelial cell function. Arzneimittel-Forsch 1994;44:416-7.

9 Auerbach W, Auerbach R. Angiogenesis inhibition: a review. Pharmacol Ther 1994;63:265-311.

10 Folkman J. Angiogenesis in cancer, vascular, rheumatoid and other disease. Nature Med 1995;1:27-31.

11 Campochiaro PA, Hackett SF, Vinores SA. Growth factors in the retina and retinal pigmented epithelium. Prog Retinal Eye Res 1997 (in press).

12 Senger DR. Molecular framework for angiogenesis. A complex web of interactions between extravasated plasma proteins and endothelial cell proteins induced by angiogenic cytokines. Am F Pathol 1996;149:1-7.

13 Ruiter DJ, Schlingemann RO, Westphal JR, Denijn M, Rietveld FJ, de Waal RM. Angiogenesis in wound healing and tumor metastasis. Behring Inst Mitt 1993:258-72.

14 D'Amore PA. Capillary growth: a two-cell system. Semin Cancer Biol 1992; 3:49-56.

15 Michaelson IC. The mode of development of the retinal vessels and some observations of its significance in certain retinal diseases. Trans Ophthalmol Soc UK 1948;68: 137-80.

16 Ashton N, Ward B, Serpell G. Effect of oxygen on developing retinal vessels with particular reference to the problem of retrolental fibroplasia. $\mathrm{Br} \mathcal{F}$ Ophthalmol 1954;38:397-405.

17 Ashton N. Retinal vascularization in health and disease. Am f Ophthalmol $1957 ; 44: 7-24$

18 Ferrara N, Heinsohn H, Walder CE, Bunting S, Thomas GR. The regulation of blood vessel growth by vascular endothelial growth factor. Ann NY Acad Sci 1995;752:246-56.

19 Dvorak HF, Brown LF, Detmar M, Dvorak AM. Vascular permeability factor/vascular endothelial growth factor, microvascular hyperpermeability, and angiogenesis. Am f Pathol 1995; 146:1029-39.

20 Thomas KA. Vascular endothelial growth factor, a potent and selective angiogenic agent. f Biol Chem 1996;271:603-6.

21 Dvorak HF, Nagy JA, Berse B, Brown LF, Yeo KT, Yeo TK, et al. Vascular permeability factor, fibrin, and the pathogenesis of tumor stroma formation. Ann NY Acad Sci 1992;667:101-11.

22 Chen SC, Chen CH. Vascular endothelial cell effectors in fetal calf retina, vitreous, and serum. Invest Ophthalmol Vis Sci 1982;23:340-50.

23 Chen CH, Chen SC. Evidence of the presence of a specific vascular endothelial growth factor in fetal bovine retina. Exp Cell Res 1987;169:28795.
24 Senger DR, Galli SJ, Dvorak AM, Perruzzi CA, Harvey VS, Dvorak HF. Tumor cells secrete a vascular permeability factor that promotes accumulation of ascites fluid. Science 1983;219:983-5.

25 Senger DR, Brown LF, Claffey KP, Dvorak HF. Vascular permeability factor, tumor angiogenesis and stroma generation. Inv Metast 1994;14:38594

26 Senger DR, Perruzzi CA, Feder J, Dvorak HF. A highly conserved vascular permeability factor secreted by a variety of human and rodent tumor cell lines. Cancer Res 1986;46:5629-32.

27 Keck PJ, Hauser SD, Krivi G, Sanzo K, Warren T, Feder J, et al. Vascular permeability factor, an endothelial cell mitogen related to PDGF. Science 1989;246:1309-12.

28 Connolly DT, Heuvelman DM, Nelson R, Olander JV, Eppley BL, Delfino $\mathrm{JJ}$, et al. Tumor vascular permeability factor stimulates endothelial cell growth and angiogenesis. $\mathcal{F}$ Clin Invest 1989;84:1470-8.

29 Conn G, Bayne ML, Soderman DD, Kwok PW, Sullivan KA, Palisi TM, et al. Amino acid and cDNA sequences of a vascular endothelial cell mitogen that is homologous to platelet-derived growth factor. Proc Natl Acad Sci USA 1990;87:2628-32.

30 Leung DW, Cachianes G, Kuang WJ, Goeddel DV, Ferrara N. Vascular endothelial growth factor is a secreted angiogenic mitogen. Science 1989;246:1306-9.

31 Tischer E, Gospodarowicz D, Mitchell R, Silva M, Schilling J, Lau K, et al. Vascular endothelial growth factor: a new member of the platelet-derived growth factor gene family. Biochem Biophys Res Commun 1989;165:1198206.

32 Ferrara N, Henzel WJ. Pituitary follicular cells secrete a novel heparinbinding growth factor specific for vascular endothelial cells. Biochem Biophys Res Commun 1989;161:851-8.

33 Favard C, Moukadiri H, Dorey C, Praloran V, Plouet J. Purification and biological properties of vasculotropin, a new angiogenic cytokine. Biol Cell 1991;73:1-6.

34 Senger DR, Connolly DT, Van de Water L, Feder J, Dvorak HF. Purification and NH2-terminal amino acid sequence of guinea pig tumor-secreted vascular permeability factor. Cancer Res 1990;50:1774-8.

35 Plouet J, Moukadiri H. Characterization of the receptor to vasculotropin on bovine adrenal cortex-derived capillary endothelial cells. F Biol Chem 1990; 265:22071-4.

36 Neufeld G, Tessler S, Gitay-Goren H, Cohen T, Levi BZ. Vascular endothelial growth factor and its receptors. Prog Growth Factor Res 1994;5:89-97.

37 Cooper JC, Sharkey AM, McLaren J, Charnock-Jones DS, Smith SK. Localization of vascular endothelial growth factor and its receptor, flt, in human placenta and decidua by immunohistochemistry. 7 Reprod Fert 1995;105:205-13.

38 Potgens AJ, Lubsen NH, van Altena MC, Vermeulen R, Bakker A, Schoenmakers JG, et al. Covalent dimerization of vascular permeability factor/vascular endothelial growth factor is essential for its biological activity. Evidence from Cys to Ser mutations. F Biol Chem 1994;269:32879-85.

39 Park JE, Chen HH, Winer J, Houck KA, Ferrara N. Placenta growth factor. Potentiation of vascular endothelial growth factor bioactivity, in vitro and in vivo, and high affinity binding to Flt-1 but not to Flk-1/KDR. F Biol Chem 1994;269:25646-54

40 Maglione D, Guerriero V, Viglietto G, Delli-Bovi P, Persico MG. Isolation of a human placenta cDNA coding for a protein related to the vascular permeability factor. Proc Natl Acad Sci USA 1991;88:9267-71.

41 Olofsson B, Pajusola K, Kaipainen A, von Euler G, Joukov V, Saksela O, et al. Vascular endothelial growth factor B, a novel growth factor for endothelial cells. Proc Natl Acad Sci USA 1996;93:2576-81.

42 Joukov V, Pajusola K, Kaipainen A, Chilov D, Lahtinen I, Kukk E, et al. A novel vascular endothelial growth factor, VEGF-C, is a ligand for the Flt4 (VEGFR-3) and KDR (VEGFR-2) receptor tyrosine kinases. EMBO f 1996;15:290-8.

43 Lee J, Gray A, Yuan J, Luoh S-M, Avraham H, Wood WI. Vascular endothelial growth factor-related protein: a ligand and specific activator of the tyrosine kinase receptor Flt4. Proc Natl Acad Sci USA 1996;93:1988-92.

44 Senger DR, Ledbetter SR, Claffey KP, Papadopoulos-Sergiou A, Perruzzi CA, Detmar M. Stimulation of endothelial cell migration by vascular permeability factor/ vascular endothelial growth factor through cooperative mechanisms involving the $\alpha_{v} \beta_{3}$ integrin, osteopontin, and thrombin. Am $\mathcal{F}$ Pathol 1996; 149:293-305.

45 Potgens AJ, Westphal HR, de Waal RM, Ruiter DJ. The role of vascular permeability factor and basic fibroblast growth factor in tumor angiogenesis. Biol Chem Hoppe-Seyler 1995;376:57-70.

46 Zagzag D. Angiogenic growth factors in neural embryogenesis and neoplasia. Am f Pathol 1995;146:293-309.

47 Freeman MR, Schneck FX, Gagnon ML, Corless C, Soker S, Niknejad K, et al. Peripheral blood T lymphocytes and lymphocytes infiltrating human cancers express vascular endothelial growth factor: a potential role for $\mathrm{T}$ cells in angiogenesis. Cancer Res 1995;55:4140-5.

48 Fischer S, Sharma HS, Karliczek GF, Schaper W. Expression of vascular permeability factor/vascular endothelial growth factor in pig cerebral microvascular endothelial cells and its upregulation by adenosine. $\mathrm{Mol}$ Brain Res 1995;28:141-8.

49 Ladoux A, Frelin C. Expression of vascular endothelial growth factor by cultured endothelial cells from brain microvessels. Biochem Biophys Res Commun 1993;194:799-803.

50 Tischer E, Mitchell R, Hartman T, Silva M, Gospodarowicz D, Fiddes JC, et al. The human gene for vascular endothelial growth factor. Multiple pro-
tein forms are encoded through alternative exon splicing. $\mathcal{F}$ Biol Chem tein forms are encoded

51 Park JE, Keller GA, Ferrara N. The vascular endothelial growth factor (VEGF) isoforms: differential deposition into the subepithelial extracellular matrix and bioactivity of extracellular matrix-bound VEGF. Mol Biol Cell 1993;4:1317-26.

52 Folkman J, Shing Y. Control of angiogenesis by heparin and other sulfated polysaccharides. Adv Exp Med Biol 1992;313:355-64.

53 Houck KA, Leung DW, Rowland AM, Winer J, Ferrara N. Dual regulation of vascular endothelial growth factor bioavailability by genetic and proteolytic mechanisms. F Biol Chem 1992;267:26031-7.

54 Keyt BA, Berleau LT, Nguyen HV, Chen H, Heinsohn H, Vandlen R, et al. The carboxyl-terminal domain (111-165) of vascular endothelial growth factor is critical for its mitogenic potency. $\mathcal{F}$ Biol Chem 1996;271:7788-95. 
55 Collins PD, Connolly DT, Williams TJ. Characterization of the increase in vascular permeability induced by vascular permeability factor in vivo. $B r \mathcal{F}$ vascular permeability induced

56 Connolly DT. Vascular permeability factor: a unique regulator of blood vessel function. F Cell Biochem 1991;47:219-23.

57 Roberts WG, Palade GE. Increased microvascular permeability and endothelial fenestration induced by vascular endothelial growth factor. $\mathcal{F}$ Cell Sci 1995;108:2369-79.

58 Nagy JA, Masse EM, Herzberg KT, Meyers MS, Yeo KT, Yeo TK, et al. Pathogenesis of ascites tumor growth: vascular permeability factor, vascular hyperpermeability, and ascites fluid accumulation. Cancer Res 1995;55: 360-8.

59 McClure N, Healy DL, Rogers PA, Sullivan J, Beaton L, Haning RV Jr, et al. Vascular endothelial growth factor as capillary permeability agent in ovarian hyperstimulation syndrome. Lancet 1994;344:235-6.

60 Berkman RA, Merrill MJ, Reinhold WC, Monacci WT, Saxena A, Clark WC, et al. Expression of the vascular permeability factor/vascular endothelial growth factor gene in central nervous system neoplasms. $\mathcal{F}$ Clin Invest 1993;91:153-9.

61 Criscuolo GR. The genesis of peritumoral vasogenic brain edema and tumor cysts: a hypothetical role for tumor-derived vascular permeability tumor cysts: a hypothetical role for tum
factor. Yale $\mathcal{F}$ Biol Med 1993;66:277-314.

62 Brown LF, Harrist TJ, Yeo KT, Stahle-Backdahl M, Jackman RW, Berse B, et al. Increased expression of vascular permeability factor (vascular endothelial growth factor) in bullous pemphigoid, dermatitis herpetiformis, and erythema multiforme. F Invest Dermatol 1995;104:744-9.

63 Detmar M, Brown LF, Claffey KP, Yeo KT, Kocher O, Jackman RW, et al. Overexpression of vascular permeability factor/vascular endothelial growth factor and its receptors in psoriasis. F Exp Med 1994;180:1141-6.

64 Wilting J, Christ B, Bokeloh $M$, Weich HA. In vivo effects of vascular endothelial growth factor on the chicken chorioallantoic membrane. Cell Tiss Res 1993;274:163-72.

65 Kenyon BM, Voest EV, Chen CC, Flynn E, Folkman J, D'Amato RJ. A model of angiogenesis in the mouse cornea. Invest Ophthalmol Vis Sci 1996; 37:1625-32.

66 Pepper MS, Wasi S, Ferrara N, Orci L, Montesano R. In vitro angiogenic and proteolytic properties of bovine lymphatic endothelial cells. Exp Cell Res 1994;210:298-305.

67 Pepper MS, Ferrara N, Orci L, Montesano R. Potent synergism between vascular endothelial growth factor and basic fibroblast growth factor in the induction of angiogenesis in vitro. Biochem Biophys Res Commun 1992;189: 824-31.

68 Koolwijk P, van Erck MG, de Vree WJ, Vermeer MA, Weich HA, Hanemaaiijer R, et al. Cooperative effect of TNFalpha, bFGF, and VEGF on the formation of tubular structures of human microvascular endothelial cells in a fibrin matrix. Role of urokinase activity. $\mathcal{f}$ Cell Bio 1996:132:1177-88.

69 Pekala P, Marlow M, Heuvelman D, Connolly D. Regulation of hexose transport in aortic endothelial cells by vascular permeability factor and tumor necrosis factor-alpha, but not by insulin. F Biol Chem 1990;265: 18051-4.

70 Unemori EN, Ferrara N, Bauer EA, Amento EP. Vascular endothelial growth factor induces interstitial collagenase expression in human endothelial cells. F Cell Physiol 1992;153:557-62.

71 Mandriota SJ, Seghezzi G, Vassalli JD, Ferrara N, Wasi S, Mazzieri R, et al. Vascular endothelial growth factor increases urokinase receptor expression in vascular endothelial cells. F Biol Chem 1995;270:9709-16.

72 Pepper MS, Ferrara N, Orci L, Montesano R. Vascular endothelial growth factor (VEGF) induces plasminogen activators and plasminogen activator
inhibitor-1 in microvascular endothelial cells. Biochem Biophys Res Commun 1991; 181:902-6.

73 Brooks PC, Clark RA, Cheresh DA. Requirement of vascular integrin alpha $\mathrm{v}$ beta 3 for angiogenesis. Science 1994;264:569-71.

74 Friedlander M, Brooks PC, Shaffer RW, Kincaid CM, Varner JA, Cheresh DA, et al. Definition of two angiogenic pathways by distinct alpha $\mathrm{v}$ integrins. Science 1995;270:1500-2.

75 Friedlander M, Theesfeld CL, Sugita M, Fruttiger M, Thomas MA, Chang S, et al. Involvement of integrins $\alpha_{\mathrm{v}} \beta_{3}$ and $\alpha_{\mathrm{v}} \beta_{5}$ in ocular neovascular disease. Proc Natl Acad Sci USA 1996;93:9764-9.

76 Vaisman N, Gospodarowicz D, Neufeld G. Characterization of the receptors for vascular endothelial growth factor. F Biol Chem 1990;265:19461-6.

77 Terman BI, Dougher-Vermazen M, Carrion ME, Dimitrov D, Armellino DC, Gospodarowicz D, et al. Identification of the KDR tyrosine kinase as a receptor for vascular endothelial cell growth factor. Biochem Biophys Res Commun 1992;187:1579-86.

78 Quinn TP, Peters KG, De Vries C, Ferrara N, Williams LT. Fetal liver kinase 1 is a receptor for vascular endothelial growth factor and is selectively expressed in vascular endothelium. Proc Natl Acad Sci U S A 1993;90:7533-7

79 Waltenberger J, Claesson-Welsh L, Siegbahn A, Shibuya M, Heldin CH. Different signal transduction properties of KDR and Flt1, two receptors for vascular endothelial growth factor. F Biol Chem 1994;269:26988-95.

80 Mustonen T, Alitalo K. Endothelial receptor tyrosine kinases involved in angiogenesis. F Cell Biol 1995;129:895-8.

81 Takagi H, King GL, Ferrara N, Aiello LP. Hypoxia regulates vascular endothelial growth factor receptor $\mathrm{KDR} / \mathrm{Flk}$ gene expression through adenosine A2 receptors in retinal capillary endothelial cells. Invest Ophthalmol Vis Sci 1996;37:1311-21.

82 Plate KH, Breier G, Weich HA, Risau W. Vascular endothelial growth factor is a potential tumour angiogenesis factor in human gliomas in vivo. Nature 1992;359:845-8.

83 Takahashi Y, Kitadai Y, Bucana CD, Cleary KR, Ellis LM. Expression of vascular endothelial growth factor and its receptor, KDR, correlates with vascularity, metastasis, and proliferation of human colon cancer. Cancer Res 1995;55:3964-8.

84 Hatva E, Kaipainen A, Mentula P, Jaaslekainen J, Paetau A, Haltia M, et al. Expression of endothelial cell-specific receptor tyrosine kinases and growth factors in human brain tumors. Am F Pathol 1995;146:368-78.

85 Brown LF, Berse B, Jackman RW, Tognazzi K, Manseau EJ, Dvorak HF, et $a l$. Increased expression of vascular permeability factor (vascular endothelial growth factor) and its receptors in kidney and bladder carcinomas. $\mathrm{Am}$ f Pathol 1993;143:1255-62.
86 Brown LF, Yeo KT, Berse B, Yeo TK, Senger DR, Dvorak HF, et al. Expression of vascular permeability factor (vascular endothelial growth factor) by epidermal keratinocytes during wound healing. $\mathcal{F}$ Exp Med 1992;176:1375-

87 Barleon B, Hauser S, Schollmann C, Weindel K, Marme D, Yagon A, et al. Differential expression of the two VEGF receptors flt and KDR in placenta and vascular endothelial cells. $\mathcal{F}$ Cell Biochem 1994;54:56-66.

88 Brogi E, Schatteman G, Wu T, Kim EA, Varticovski L, Keyt B, et al. Hypoxia-induced paracrine regulation of vascular endothelial growth factor receptor expression. $\mathcal{F}$ Clin Invest 1996;97:469-76.

89 Mandriota SJ, Menoud PA, Pepper MS. Transforming growth factor beta 1 down-regulates vascular endothelial growth factor receptor 2/flk-1 expression in vascular endothelial cells. F Biol Chem 1996;271:11500-5.

90 Gruber BL, Marchese MJ, Kew R. Angiogenic factors stimulate mast-cell migration. Blood 1995;86:2488-93.

91 Oberg C, Waltenberger J, Claesson-Welsh L, Welsh M. Expression of protein tyrosine kinases in islet cells: possible role of the Flk-1 receptor for protein tyrosine kinases in islet cells: possible role of the Flk-1 receptor

92 Clauss M, Gerlach M, Gerlach H, Brett J, Wang F, Familetti PC, et al. Vascular permeability factor: a tumor-derived polypeptide that induces endothelial cell and monocyte procoagulant activity, and promotes monocyte migration. $\mathcal{F}$ Exp Med 1990;172:1535-45.

93 Katoh O, Tauchi H, Kawaishi K, Kimura A, Satow Y. Expression of the vascular endothelial growth factor (VEGF) receptor gene, KDR, in
hematopoietic cells and inhibitory effect of VEGF on apoptotic cell death caused by ionizing radiation. Cancer Res 1995;55:5687-92.

94 Hackett SF, Schoenfeld CL, Chen YS, Vinores MA, Campochiaro PA. Receptors for VEGF (flt-1 and flk-1) are expressed in nonvascular cells in the eye. Invest Ophthalmol Vis Sci 1996;37:S794.

95 Takahashi T, Shirasawa T, Miyake K, Yahagi Y, Maruyama N, Kasahara N, et al. Protein tyrosine kinases expressed in glomeruli and cultured glomerular cells: Flt-1 and VEGF expression in renal mesangial cells. Biochem Biophys Res Commun 1995;209:218-26.

96 Nomura M, Yamagishi S, Harada S, Hayashi Y, Yamashima T, Yamashita J, et al. Possible participation of autocrine and paracrine vascular endothelial growth factors in hypoxia-induced proliferation of endothelial cells and growth factors in hypoxia-induced prolife
pericytes. $\mathcal{F}$ Biol Chem 1995;270:28316-24.

97 Barleon B, Sozzani S, Zhou D, Weich HA, Mantovani A, Marme D. Migration of human monocytes in response to vascular endothelial growth factor (VEGF) is mediated via the VEGF receptor flt-1. Blood 1996;87:3336-43.

98 Takagi H, King GL, Aiello LP. Identification and characterization of vascular endothelial growth factor receptor (Flt) in bovine retinal pericytes. Diabetes 1996;45:1016-23.

99 Ortega N, Dos Santos D, Plouet J. Activation of the VEGF receptor flt-1 mediates corneal endothelial cell migration and permeability. Invest Ophthalmol Vis Sci 1996;37:S88.

100 Grosskreutz CL, Anand-Apte B, Terman B, Quinn TP, D' Amore PA. Vascular endothelial growth factor (VEGF) is a chemoattractant for vascular smooth muscle cells (SMC). Invest Ophthalmol Vis Sci 1996;37:S470.

101 Guerrin M, Moukadiri H, Chollet P, Moro F, Dutt K, Malecaze F, et al. Vasculotropin/vascular endothelial growth factor is an autocrine growth factor for human retinal pigment epithelial cells cultured in vitro. $\mathcal{f}$ Cell factor for human retinal
Physiol 1995;164:385-94.

102 Lachgar S, Moukadiri H, Jonca F, Charveron M, Bouhaddioui N, Gall Y, et al. Vascular endothelial growth factor is an autocrine growth factor for hair dermal papilla cells. F Invest Dermatol 1996;106:17-23.

103 Kaipainen A, Korhonen J, Mustonen T, vanHinsbergh VW, Fang GH, Dumont D, et al. Expression of the fms-like tyrosine kinase 4 gene becomes restricted to lymphatic endothelium during development. Proc Natl Acad Sci USA 1995;92:3566-70.

104 Stone J, Itin A, Alon T, Pe'er J, Gnessin H, Chan-Ling T, et al. Development of retinal vasculature is mediated by hypoxia-induced vascular endothelial growth factor (VEGF) expression by neuroglia. I Neurosci 1995;15:4738-47.

105 Millauer B, Wizigmann-Voos S, Schnurch H, Martinez R, Moller NP, Risau W, et al. High affinity VEGF binding and developmental expression suggest Flk-1 as a major regulator of vasculogenesis and angiogenesis. Cell 1993;72:835-46.

106 Breier G, Albrecht U, Sterrer S, Risau W. Expression of vascular endothelial growth factor during embryonic angiogenesis and endothelial cell differentiation. Development 1992;114:521-32.

107 Plate KH, Breier G, Risau W. Molecular mechanisms of developmental and tumor angiogenesis. Brain Pathol 1994;4:207-18.

108 Simon M, Grone HJ, Johren O, Kullmer J, Plate KH, Risau W, et al. Expression of vascular endothelial growth factor and its receptors in human renal ontogenesis and in adult kidney. Am f Physiol 1995;268:F240-50.

109 Peters KG, De Vries C, Williams LT. Vascular endothelial growth factor receptor expression during embryogenesis and tissue repair suggests a role in endothelial differentiation and blood vessel growth. Proc Natl Acad Sci USA 1993;90:8915-9.

110 Breier G, Clauss M, Risau W. Coordinate expression of vascular endothelial growth factor receptor-1 (flt-1) and its ligand suggests a paracrine regulation of murine vascular development. Dev Dyn 1995;204:228-39.

111 Alon T, Hemo I, Itin A, Pe'er J, Stone J, Keshet E. Vascular endothelial growth factor acts as a survival factor for newly formed retinal vessels and has implications for retinopathy of prematurity. Nature Med 1995;1:1024-

112 Pierce EA, Foley ED, Smith LEH. Regulation of vascular endothelial growth factor by oxygen in a model of retinopathy of prematurity. Arch Ophthalmol 1996;114:1219-28.

113 Shalaby F, Rossant J, Yamaguchi TP, Gertsenstein M, Wu XF, Breitman ML, et al. Failure of blood-island formation and vasculogenesis in Flk-1-deficient mice. Nature 1995;376:62-6.

114 Fong GH, Rossant J, Gertsenstein M, Breitman ML. Role of the Flt-1 receptor tyrosine kinase in regulating the assembly of vascular endothelium. Nature 1995;376:66-70.

115 Ferrara N, Carver-Moore K, Chen H, Dowd M, Lu L, O'Shea KS, et al. Heterozygous embryonic lethality induced by targeted inactivation of the VEGF gene. Nature 1996;380:439-42.

116 Carmeliet P, Ferreira V, Breier G, Pollefeyt S, Kieckens L, Gertsenstein M, et al. Abnormal blood vessel development and lethality in embryos lacking a single VEGF allele. Nature 1996;380:435-9.

117 Gengrinovitch S, Greenberg SM, Cohen T, Gitay-Goren H, Rockwell P, Maione TE, et al. Platelet factor-4 inhibits the mitogenic activity of 
VEGF121 and VEGF165 using several concurrent mechanisms. I Biol Chem 1995;270:15059-65.

118 Pepper MS, Vassalli JD, Orci L, Montesano R. Biphasic effect of transforming growth factor-beta 1 on in vitro angiogenesis. Exp Cell Res 1993;204:356-63.

119 Takahashi A, Sasaki H, Kim SJ, Tobisu K, Kakizoe T, Tsukamoto T, et al. Markedly increased amounts of messenger RNAs for vascular endothelial
growth factor and placenta growth factor in renal cell carcinoma associated with angiogenesis. Cancer Res 1994;54:4233-7.

120 Goto F, Goto K, Weindel K, Folkman J. Synergistic effects of vascular endothelial growth factor and basic fibroblast growth factor on the proliferation and cord formation of bovine capillary endothelial cells within proliferation and cord formation of bovine
collagen gels. Lab Invest 1993;69:508-17.

121 Asahara T, Bauters C, Zheng LP, Takeshita S, Bunting S, Ferrara N, et al. Synergistic effect of vascular endothelial growth factor and basic fibroblast Synergistic effect of vascular endothelial growth factor and basic fibrob
growth factor on angiogenesis in vivo. Circulation 1995; 92:11365-71.

122 Brogi E, Wu T, Namiki A, Isner JM. Indirect angiogenic cytokines upregulate VEGF and bFGF gene expression in vascular smooth muscle cells, whereas hypoxia upregulates VEGF expression only. Circulation 1994;90: 649-52.

123 Stavri GT, Zachary IC, Baskerville PA, Martin JF, Erusalimsky JD. Basic fibroblast growth factor upregulates the expression of vascular endothelial growth factor in vascular smooth muscle cells. Synergistic interaction with hypoxia. Circulation 1995;92:11-4.

124 Williams B, Baker AQ, Gallacher B, Lodwick D. Angiotensin II increases vascular permeability factor gene expression by human vascular smooth vascular permeability factor gene expressich
muscle cells. Hypertension 1995;25:913-7.

125 Tsai JC, Goldman CK, Gillespie GY. Vascular endothelial growth factor in human glioma cell lines: induced secretion by EGF, PDGF-BB, and bFGF. f Neurosurg 1995;82:864-73.

126 Stavri GT, Hong Y, Zachary IC, Breier G, Baskerville PA, Yla-Herttualla $\mathrm{S}$, et al. Hypoxia and platelet-derived growth factor-BB synergistically upregulate the expression of vascular endothelial growth factor in vascular smooth muscle cells. FEBS Lett 1995;358:311-5.

127 Goldman CK, Kim J, Wong WL, King V, Brock T, Gillespie GY. Epidermal growth factor stimulates vascular endothelial growth factor production by human malignant glioma cells: a model of glioblastoma multiforme pathophysiology. Mol Biol Cell 1993;4:121-33.

128 Ben-Av P, Crofford LJ, Wilder RL, Hla T. Induction of vascular endothelial growth factor expression in synovial fibroblasts by prostaglandin $\mathrm{E}$ and interleukin-1: a potential mechanism for inflammatory angiogenesis. FEBS Lett 1995;372:83-7.

129 Punglia R, Kuroki M, Tolentino MJ, Hsu J, Keough K, D'Amato R, et al. IGF-1 increases VEGF mRNA and secreted protein in retinal cells. Invest Ophthalmol Vis Sci 1996;37:S794.

130 Hanahan D, Folkman J. Patterns and emerging mechanisms of the angiogenic switch during tumorigenesis. Cell 1996;86:353-64.

131 Monacci WT, Merrill MJ, Oldfield EH. Expression of vascular permeability factor/vascular endothelial growth factor in normal rat tissues. $\mathrm{Am} \mathrm{f}$ Physiol 1993;264:C995-1002.

132 Claffey KP, Wilkison WO, Spiegelman BM. Vascular endothelial growth factor. Regulation by cell differentiation and activated second messenger factor. Regulation by cell differentiation an
pathways. F Biol Chem 1992;267:16317-22.

133 Berse B, Brown LF, Van de Water L, Dvorak HF, Senger DR. Vascular permeability factor (vascular endothelial growth factor) gene is expressed differentially in normal tissues, macrophages, and tumors. Mol Biol Cell 1992;3:211-20.

134 Uchida K, Uchida S, Nitta K, Yumura W, Marumo F, Nihei H. Glomerular endothelial cells in culture express and secrete vascular endothelial growth factor. Am $\mathcal{F}$ Physiol 1994;266:F81-8.

135 Brown LF, Berse B, Tognazzi K, Manseau EJ, Van de Water L, Senger DR, et al. Vascular permeability factor mRNA and protein expression in human kidney. Kidney Int 1992;42:1457-61.

136 Yamane A, Seetharam L, Yamaguchi S, Gotoh N, Takahashi T, Neufeld G, et al. A new communication system between hepatocytes and sinusoidal endothelial cells in liver through vascular endothelial growth factor and Flt tyrosine kinase receptor family (Flt-1 and KDR/Flk-1). Oncogene tyrosine kinase
$1994 ; 9: 2683-90$

137 Hang J, Kong L, Gu JW, Adair TH. VEGF gene expression is upregulated in electrically stimulated rat skeletal muscle. Am f Physiol 1995;269:

138 Carroll SM, Nimmo LE, Knoepfler PS, White FC, Bloor CM. Gene expression in a swine model of right ventricular hypertrophy: intercellular adhesion molecule, vascular endothelial growth factor and plasminogen activators are upregulated during pressure overload. $f$ Mol Cell Cardiol 1995;27:1427-41.

139 Ladoux A, Frelin C. Hypoxia is a strong inducer of vascular endothelial growth factor mRNA expression in the heart. Biochem Biophys Res Commun 1993;195:1005-10.

140 Hashimoto E, Ogita T, Nakaoka T, Matsuoka R, Takao A, Kira Y. Rapid induction of vascular endothelial growth factor expression by transient ischemia in rat heart. Am f Physiol 1994;267:H1948-54.

141 Banai S, Shweiki D, Pinson A, Chandra M, Lazarovici G, Keshet E. Upregulation of vascular endothelial growth factor expression induced by myocardial ischaemia: implications for coronary angiogenesis. Cardiovasc Res 1994;28:1176-9.

$142 \mathrm{Ku}$ DD, Zaleski JK, Liu S, Brock TA. Vascular endothelial growth factor induces EDRF-dependent relaxation in coronary arteries. Am f Physiol 1993;265:H586-92

143 Kuroda M, Oka T, Oka Y, Yamochi T, Ohtsubo K, Mori S, et al. Colocalization of vascular endothelial growth factor (vascular permeability factor) and insulin in pancreatic islet cells. F Clin Endocrinol Met 1995;80:3196200.

144 Broxmeyer HE, Cooper S, Li ZH, Lu HL, Song HY, Kwon BS, et al. Myeloid progenitor cell regulatory effects of vascular endothelial cell growth factor. Int $\mathcal{F}$ Hematol 1995;62:203-15.

145 Shweiki D, Itin A, Soffer D, Keshet E. Vascular endothelial growth factor induced by hypoxia may mediate hypoxia-initiated angiogenesis. Nature 1992;359:843-5.

146 Plate KH, Risau W. Angiogenesis in malignant gliomas. GLIA 1995;15: $339-47$.

147 Shweiki D, Itin A, Neufeld G, Gitay-Goren H, Keshet E. Patterns of expression of vascular endothelial growth factor (VEGF) and VEGF recep- tors in mice suggest a role in hormonally regulated angiogenesis. $f \mathrm{Clin}$ Invest 1993;91:2235-43.

LF, Manseau EJ, Senger DR, Dvorak HF. Expression of vascular permeability factor/vascular endothelial growth factor by human granulosa and theca lutein cells. Role in corpus luteum development. Am $\mathcal{F}$

149 Pathol 1995;146:157-65. permeability factor expression in the rat uterus: rapid stimulation by estrogen correlates with estrogen-induced increases in uterine capillary permeability and growth. Endocrinology 1993;133:829-37.

150 Wheeler T, Elcock CL, Anthony FW. Angiogenesis and the placental environment. Placenta 1995;16:289-96.

151 Fava RA, Olsen NJ, Spencer-Green G, Yeo KT, Yeo TK, Berse B, et al. Vascular permeability factor/endothelial growth factor (VPF/VEGF): accumulation and expression in human

152 Wizigmann-Voos S, Breier G, Risau W, Plate KH. Up-regulation of vascular endothelial growth factor and its receptors in von Hippel-Lindau disease-associated and sporadic hemangioblastomas. Cancer Res 1995;55: 1358-64.

153 Morii K, Tanaka R, Washiyama K, Kumanishi T, Kuwano R. Expression of vascular endothelial growth factor in capillary hemangioblastoma. Biochem Biophys Res Commun 1993;194:749-55.

154 Ferrara N, Winer J, Burton T. Aortic smooth muscle cells express and secrete vascular endothelial growth factor. Growth Factors 1991;5:141-8.

155 Guidi AJ, Abu-Jawdeh G, Berse B, Jackman RW, Tognazzi K, Dvorak HF, et al. Vascular permeability factor (vascular endothelial growth factor) expression and $87: 1237-45$.

156 Potgens AJ, Lubsen NH, van Altena MC, Schoenmakers JG, Ruiter DJ, deWaal RM. Vascular permeability factor expression influences tumor angiogenesis in human

157 O'Brien T, Cranston D, Fuggle S, Bicknell R, Harris AL. Different angiogenic pathways characterize superficial and invasive bladder cancer. angiogenic pathways chara
Cancer Res 1995;55:510-3.

158 Potgens AJ, van Altena MC, Lubsen NH, Ruiter DJ, de Waal RM. Analysis of the tumor vasculature and metastatic behavior of xenografts of human melanoma cell lines transfected with vascular permeability factor. $A m \mathcal{F}$ Pathol 1996;148:1203-17.

$159 \mathrm{Kim} \mathrm{KJ}, \mathrm{Li} \mathrm{B}$, Winer J, Armanini M, Gillet N, Phillips HS, et al. Inhibition of vascular endothelial growth factor-induced angiogenesis suppresses tumour growth in vivo. Nature 1993;362:841-4.

160 Kondo S, Asano M, Suzuki H. Significance of vascular endothelial growth factor/vascular permeability factor for solid tumor growth, and its inhibition by the antibody. Biochem Biophys Res Commun 1993;194:123441.

161 Warren RS, Yuan H, Matli MR, Gillett NA, Ferrara N. Regulation by vascular endothelial growth factor of human colon cancer tumorigenesis in a mouse model of experimental liver metastasis. F Clin Invest 1995;95:178997.

162 Saleh M, Stacker SA, Wilks AF. Inhibition of growth of C6 glioma cells in vivo by expression of antisense vascular endothelial growth factor sequence. 6;56:393-401.

163 Millauer B, Shawver LK, Plate KH, Risau W, Ullrich A. Glioblastoma growth inhibited in vivo by a dominant-negative Flk-1 mutant. Nature

164 Millauer B, Longhi MP, Plate KH, Shawver LK, Risau W, Ullrich A, et al. Dominant-negative inhibition of Flk-1 suppresses the growth of many tumor types in vivo. Cancer Res 1996;56:1615-20.

165 Ikeda E, Achen MG, Breier G, Risau W. Hypoxia-induced transcriptional activation and increased mRNA stability of vascular endothelial growth factor in C6 glioma cells. F Biol Chem 1995;270:19761-6.

166 Hashimoto E, Kage K, Ogita T, Nakaoka T, Matsuoka R, Kira Y. Adenosine as an endogenous mediator of hypoxia for induction of vascular endothelial growth factor mRNA in U-937 cells. Biochem Biophys Res Commun 1994;204: 318-24.

167 Aiello LP, Northrup JM, Keyt BA, Takagi H, Iwamoto MA. Hypoxic regulation of vascular endothelial growth factor in retinal cells. Arch Ophthalmol 1995;113:1538-44.

168 Takagi H, King GL, Robinson GS, Ferrara N, Aiello NP. Adenosine mediates hypoxic induction of vascular endothelial growth factor in retinal pericytes and endothelial cells. Invest Ophthalmol Vis Sci 1996;37:2165-76.

169 Liu Y, Cox SR, Morita T, Kourembanas S. Hypoxia regulates vascular endothelial growth factor gene expression in endothelial cells. Identification of a 5' enhancer. Circ Res 1995;77:638-43.

170 Namiki A, Brogi E, Kearney M, Kim EA, Wu T, Couffinhal T, et al. Hypoxia induces vascular endothelial growth factor in cultured human endothelial cells. F Biol Chem 1995;270:31189-95.

171 Minchenko A, Bauer T, Salceda S, Caro J. Hypoxic stimulation of vascular endothelial growth factor expression in vitro and in vivo. Lab Invest 1994; 71:374-9.

172 Shweiki D, Neeman M, Itin A, Keshet E. Induction of vascular endothelial growth factor expression by hypoxia and by glucose deficiency in multicell spheroids: implications for tumor angiogenesis. Proc Natl Acad Sci USA 1995;92:768-72.

173 Stein I, Neeman M, Shweiki D, Itin A, Keshet E. Stabilization of vascular endothelial growth factor mRNA by hypoxia and hypoglycemia and coregulation with other ischemia-induced genes. Mol Cell Biol 1995;15:
5363-8.

174 Waleh NS, Brody MD, Knapp MA, Mendonca HL, Lord EM, Koch CJ, et al. Mapping of the vascular endothelial growth factor-producing hypoxic cells in multicellular tumor spheroids using a hypoxia-specific marker. Cancer Res 1995;55:6222-6.

175 Plate KH, Risau W. Angiogenesis in malignant gliomas. GLIA 1995;15: $339-47$

176 Goldberg MA, Schneider TJ. Similarities between the oxygen-sensing mechanisms regulating the expression of vascular endothelial growth factor and erythropoietin. 7 Biol Chem 1994;269:4355-9.

177 Minchenko A, Salceda S, Bauer T, Caro J. Hypoxia regulatory elements of the human vascular endothelial growth factor gene. Cell Mol Biol Res 1994; 40:35-9.

178 Fandrey J. Hypoxia-inducible gene expression. Resp Physiol 1995;101:110. 
179 Gleadle JM, Ebert BL, Firth JD, Ratcliffe PJ. Regulation of angiogenic growth factor expression by hypoxia, transition metals, and chelating

180 Levy AP, Levy NS, Wegner S, Goldberg MA. Transcriptional regulation of the rat vascular endothelial growth factor gene by hypoxia. $\mathcal{F}$ Biol Chem 1995;270:13333-40

181 Mukhopadhyay D, Tsiokas L, Zhou XM, Foster D, Brugge JS, Sukhatme VP. Hypoxic induction of human vascular endothelial growth factor expression through c-Src activation. Nature 1995;375:577-81.

182 Finkenzeller G, Technau A, Marme D. Hypoxia-induced transcription of the vascular endothelial growth factor gene is independent of functional

183 SP-1 transcription factor. Biochem Biophys Res Commun 1995;208:432-9. endothelial growth factor (VEGF) in human epithelial cells is mediated by increases in mRNA stability. FEBS Lett 1995;370:203-8.

184 Levy AP, Levy NS, Goldberg MA. Post-transcriptional regulation of vascular endothelial growth factor by hypoxia. F Biol Chem 1996;271:274653.

185 Gnarra JR, Zhou SB, Merrill MJ, Wagner JR, Krumm A, Papavassiliou E, et al. Post-transcriptional regulation of vascular endothelial growth factor mRNA by the product of the VHL tumor suppressor gene. Proc Natl Acad Sci USA 1996;93:10589-94

186 Kieser A, Weich HA, Brandner G, Marme D, Kolch W. Mutant p53 potentiates protein kinase $\mathrm{C}$ induction of vascular endothelial growth factor expression. Oncogene 1994;9:963-9.

187 Mukhopadhyay D, Tsiokas L, Sukhatme VP. Wild-type p53 and v-Src exert opposing influences on human vascular endothelial growth factor gene expression. Cancer Res 1995;55:6161-5.

188 Siemeister G, Weindel K, Mohrs K, Barleon B, Martiny Baron G, Marme D. Reversion of deregulated expression of vascular endothelial growth factor in human renal carcinoma cells by von Hippel-Lindau tumor suppressor protein. Cancer Res 1996;56:2299-301.

189 Plate KH, Breier G, Weich HA, Mennel HD, Risau W. Vascular endothelial growth factor and glioma angiogenesis: coordinate induction of VEGF receptors, distribution of VEGF protein and possible in vivo regulatory receptors, distribution of VEGF protein
mechanisms. Int f Cancer 1994;59:520-9.

190 Phillips GD, Stone AM, Jones BD, Schultz JC, Whitehead RA, Knighton $\mathrm{DR}$, et al. Vascular endothelial growth factor (rhVEGF165) stimulates direct angiogenesis in the rabbit cornea. In Vivo 1994;8:961-5.

191 Maybodi M, Harvey HD, Williams JM, Pepose JS, Fleming TP. Vascular endothelial growth factor is expressed in cornea. Invest Ophthalmol Vis Sci 1996;37:S1139.

192 Amano S, Tolentino MJ, Pineda R, Vinals T, Kuroki M, Adamis AP. Vascular endothelial growth factor gene expression is increased in hypoxic cornea. Invest Ophthalmol Vis Sci 1996;37:S1139.

$193 \mathrm{Li} \mathrm{CH}$, McConnell A, Garcia J, Hernandez E, Huang AJW. Expression of vascular endothelial growth factor in rabbit ocular surface epithelia. Invest Ophthalmol Vis Sci 1996;37:S863.

194 Bednarz J, Weich HA, Rodokanaki-von Schrenck A, Engelmann K. Expression of genes coding growth factors and growth factor receptors in differentiated and dedifferentiated human corneal endothelial cells. Cornea 1995;14:372-81.

195 Wise GN. Retinal neovascularization. Trans Am Ophthalmol Soc 1956;54: $729-826$.

196 Patz A. The role of oxygen in in retrolental fibroplasia. Pediatrics 1957;19: 504-24.

197 Hogeboom van Buggenum IM, van der Heijde GL, Tangelder GJ Reichert-Thoen JWM. Ocular oxygen measurement. Br f Ophthalmol 1996;80:567-73.

198 Miller JW, Adamis AP, Shima DT, D'Amore PA, Moulton RS, O'Reilly MS, et al. Vascular endothelial growth factor/vascular permeability factor is temporally and spatially correlated with ocular angiogenesis in a primate model. Am f Pathol 1994;145:574-84.

199 Adamis AP, Shima DT, Tolentino MJ, Gragoudas ES, Ferrara N, Folkman $\mathrm{J}$, et al. Inhibition of vascular endothelial growth factor prevents retinal ischemia-associated iris neovascularization in a nonhuman primate. Arch Ophthalmol 1996;114:66-71.

200 Pounaras CJ, Miller JW, Gragoudas ES, Husain D, Munoz JL, Conolly EJ, et al. Upregulation of retinal VEGF expression with ischemic hypoxia and reversal with hyperoxia or scatter photocoagulation in a monkey model. reversal with hyperoxia or scatter phot
Invest Ophthalmol Vis Sci 1996;37:S659.

201 Pe'er J, Shweiki D, Itin A, Hemo I, Gnessin H, Keshet E. Hypoxia-induced expression of vascular endothelial growth factor by retinal cells is a common factor in neovascularizing ocular diseases. Lab Invest 1995;72: 638-45.

202 Kim S, Tolentino M, Yoshida A, Kuroki M, Adamis AP. Iris neovascularization and increased retinal VEGF expression in the hypoxic adult rat. Invest Ophthalmol Vis Sci 1996;37:S120.

203 Shima DT, Gougos A, Miller JW, Tolentino M, Robinson G, Adamis AP, et al. Cloning and mRNA expression of vascular endothelial growth factor in ischemic retinas of Macaca fascicularis. Invest Ophthalmol Vis Sci 1996; 37:1334-40.

204 Pierce EA, Avery RL, Foley ED, Aiello LP, Smith LE. Vascular endothelial growth factor/vascular permeability factor expression in a mouse model of growth factor/vascular permeability factor expression in a mouse m.

205 Hata Y, Nakagawa K, Ishibashi T, Inomata H, Ueno H, Sueishi K. Hypoxia-induced expression of vascular endothelial growth factor by retinal glial cells promotes in vitro angiogenesis. Virchows Arch 1995;426: 479-86

206 Behzadian MA, Feng Y, Wang X, Plout J, Caldwell RB. Muller cells stimulate endothelial cell growth by releasing VEGF. Invest Ophthalmol Vis Sci 1996;37:S793.

207 Tolentino MJ, Miller JW, Gragoudas ES, ChatzistefanouK, Ferrara N, Adamis AP. Vascular endothelial growth factor is sufficient to produce iris neovascularization and neovascular glaucoma in a nonhuman primate. Arch Ophthmol 1996;114:964-70.

208 Ozaki H, Hayashi H, Vinores SA, Moromisato Y, Campochiaro PA, Oshima K. Intravitreal sustained release of VEGF causes breakdown of the blood-retinal barrier and retinal neovascularization. Exp Eye Res 1997 (in press).

209 Tolentino MJ, Miller JW, Gragoudas ES, Jakobiec FA, Flynn E, Chatzistefanou $\mathrm{K}$, et al. Intravitreous injections of vascular endothelial growth factor produce retinal ischemia and microangiopathy in an adult primate. Ophthalmology 1996;103:1820-8.
210 Duh E, Aiello LP, Takagi C, Clermont A, Mori F, King GL, et al. Vascular endothelial growth factor (VEGF) increases retinal vascular permeability in vivo. Invest Ophthalmol Vis Sci 1996;37:S121.

211 Vinores SA, Youssri AI, Luna JD, Chen Y-S, Bhargave S, Vinores MA, et al. Upregulation of vascular endothelial growth factor in ischemic and non-ischemic human and experimental retinal disease. Histol Histopathol 1997 (in press).

212 Laatikainen L, Blach RK. Behaviour of the iris vasculature in central retinal vein occlusion: a fluorescein angiographic study of the vascular response of the retina and the iris. Br F Ophthalmol 1977;61:272-7.

213 Shilling JS, Kohner EM. New vessel formation in retinal branch vein occlusion. Br f Ophthalmol 1976;60:810-5.

214 Laatikainen L, Kohner EM. Fluorescein angiography and its prognostic significance in central retinal vein occlusion. Br f Ophthalmol 1976;60:4118.

215 Lutty GA, McLeod S, Merges C, Diggs A, Plouet J. Localization of vascular endothelial growth factor in human retina and choroid. Arch Ophthalmol 1996;114:971-7.

216 Foreman D, Williams G, Boulton ME. VEGF distribution in proliferative diabetic retinopathy. Invest Ophthalmol Vis Sci 1996;37:S973.

217 Adamis AP, Miller JW, Bernal MT, D’Amico DJ, Folkman J, Yeo TK, et al. Increased vascular endothelial growth factor levels in the vitreous of eyes with proliferative diabetic retinopathy. Am f Ophthalmol 1994;118:445-50.

218 Aiello LP, Avery RL, Arrigg PG, Keyt BA, Jampel HD, Shah ST, et al. Vascular endothelial growth factor in ocular fluid of patients with diabetic retinopathy and other retinal disorders. $N$ Engl F Med 1994;331:1480-7.

219 Malecaze F, Clamens S, Simorre-Pinatel V, Mathis A, Chollet P, Favard C, et al. Detection of vascular endothelial growth factor messenger RNA and retinopathy. Arch Ophthalmol 1994;112:1476-82.

220 Grant MB, Mames RN, Fitzgerald C, Ellis EA, Caballero S, Chegini N, et al. Insulin-like growth factor I as an angiogenic agent. In vivo and in vitro studies. Ann NY Acad Sci 1993;692:230-42.

221 Sone H, Okuda Y, Kawakami Y, Hanatani M, Suzuki H, Kozawa T, et al. Vascular endothelial growth factor level in aqueous humor of diabetic patients with rubeotic glaucoma is markedly elevated. Diabetes Care 1996; 19:1306-7.

222 Williamson JR, Chang KC, LeJeune W, Stephan CC, Brock TA, Tilton RG. Links between retinal vascular dysfunction induced by elevated glucose levels and VEGF. Invest Ophthalmol Vis Sci 1996;37:S969.

223 Murata T, Nakagawa K, Khalil A, Ishibashi T, Inomata H, Sueishi K. The relation between expression of vascular endothelial growth factor and breakdown of the blood-retinal barrier in diabetic rat retinas. Lab Invest 1996;74:819-25.

224 Amin RH, Frank RN, Eliott D, Kennedy A, Puklin JE, Abrams GW. Vascular endothelial growth factor is present in glial cells of the retina and optic nerve of human subjects with nonproliferative diabetic retinopathy. Invest Ophthalmol Vis Sci 1997;38:36-47.

225 Frank RN, Amin RH, Kennedy A, Hohman TC. The aldose reductase inhibitor ARI-509 blocks retinal VEGF expression in the long term galactosemic rat. Invest Ophthalmol Vis Sci 1996;37:S204.

226 Gartner S, Henkind P. Neovascularization of the iris (rubeosis iridis). Surv Ophthalmol 1978;22:291-312.

227 Vinores SA, Kuchle M, Mahlow J, Chiu C, Green WR, Campochiaro PA. Blood-ocular barrier breakdown in eyes with ocular melanoma. A potential role for vascular endothelial growth factor/vascular permeability factor. $\mathrm{Am}$ 7 Pathol 1995; 147:1289-97.

228 Dorey CK, Aouididi S, Reynaud X, Dvorak HF, Brown LF. Correlation of vascular permeability factor/vascular endothelial growth factor with extraretinal neovascularization in the rat. Arch Ophthalmol 1996;114:12107

229 Murata T, Nakagawa K, Khalil A, Ishibashi T, Inomata H, Sueishi K. The temporal and spatial vascular endothelial growth factor expression in retinal vasculogenesis of rat neonates. Lab Invest 1996;74:68-77.

230 Ashton N. Oxygen and the growth and development of retinal vessels. $\mathrm{Am}$ f Ophthalmol 1966;62:412-35.

231 Stone J, Chan-Ling T, Pe'er J, Itin A, Gnessin H, Keshet E. Roles of vascular endothelial growth factor and astrocyte degeneration in the genesis of retinopathy of prematurity. Invest Ophthalmol Vis Sci 1996;37:290-9.

232 Aiello LP, Pierce EA, Foley ED, Takagi H, Chen H, Riddle L, et al. Suppression of retinal neovascularization in vivo by inhibition of vascular endothelial growth factor (VEGF) using soluble VEGF-receptor chimeric proteins. Proc Natl Acad Sci USA 1995;92:10457-61.

233 Robinson GS, Pierce EA, Rook SL, Foley E, Webb R, Smith LE. Oligodeoxynucleotides inhibit retinal neovascularization in a murine model of proliferative retinopathy. Proc Natl Acad Sci USA 1996;93:4851-6.

234 Wizigmann-Voos S, Plate KH. Pathology, genetics and cell biology of hemangioblastomas Histol Histopathol 1996;11:1049-61.

235 Iliopoulos O, Levy AP, Jiang C, Kaelin WG, Goldberg MA. Negative regulation of hypoxia-inducible genes by the von Hippel Lindau protein. Proc Natl Acad Sci USA 1996;93:10595-9.

236 Ogata N, Yi X, Yamamoto C, Uyama M, Omori K, Komada M, et al. Expression of vascular endothelial growth factor in experimental choroidal neovascularization. Invest Ophthalmol Vis Sci 1996;37:S124.

237 Lopez PF, Sippy BD, Lambert HM, Thach AB, Hinton DR. Transdifferentiated retinal pigment epithelial cells are immunoreactive for vascular endothelial growth factor in surgically excised age-related macular degeneration-related choroidal neovascular membranes. Invest Ophthalmol Vis Sci 1996;37:855-68.

238 Kvanta A, Algvere PV, Berglin L, Seregard S. Subfoveal fibrovascular membranes in age-related macular degeneration express vascular endothelial growth factor. Invest Ophthalmol Vis Sci 1996;37:1929-34

239 Kliffen M, Sharma HS, Mooy CM, Kerkvliet S, de Jong PTVM. Increased expression of angiogenic growth factors in age-related maculopathy. $\mathrm{Br} \mathcal{F}$ Ophthalmol 1997;81:154-62.

240 Adamis AP, Shima DT, Yeo KT, Yeo TK, Brown LF, Berse B, et al. Synthesis and secretion of vascular permeability factor/vascular endothelial growth factor by human retinal pigment epithelial cells. Biochem Biophys Res Commun 1993;193:631-8.

241 Kvanta A. Expression and regulation of vascular endothelial growth factor in choroidal fibroblasts. Curr Eye Res 1995;14:1015-20. 
242 Wells JA, Murthy R, Chibber R, Nunn A, Molinatti PA, Kohner EM, et al. Levels of vascular endothelial growth factor are elevated in the vitreous of patients with subretinal neovascularization. Br f Ophthalmol 1996;80:3636.

243 Kim I, Tolentino MJ, Miller JW, Adamis AP. Constitutive VEGF mRNA expression in the tissues of normal adult eyes. Invest Ophthalmol Vis Sci 1996;37:S792.

244 Kitaoka T, Amemiya T. Localization of vascular endothelial growth factor in rat ciliary body. Invest Ophthalmol Vis Sci 1996;37:S134.

245 Sakamoto T, Sakamoto H, Murphy TL, Spee C, Soriano D, Ishibashi T, et $a l$. Vessel formation by choroidal endothelial cells in vitro is modulated by retinal pigment epithelial cells. Arch Ophthalmol 1995;113:512-20.

246 Banai S, Jaklitsch MT, Shou M, Lazarous DF, Schweinowitz M, Biro S, et al. Angiogenic-induced enhancement of collateral blood flow to ischemic dogs. Circulation 1994;89:2183-9.

247 Takeshita S, Zheng LP, Brogi E, Kearney M, Pu LQ, Bunting S, et al. Therapeutic angiogenesis. A single intraarterial bolus of vascular endothelial growth factor augments revascularization in a rabbit ischemic hind limb model. F Clin Invest 1994;93:662-70.

$248 \mathrm{He}$ P, Curry FE. Differential actions of cAMP on endothelial [Ca2+]i and permeability in microvessels exposed to ATP. Am 7 Physiol 1993;265: H1019-23.

249 Asano M, Yukita A, Matsumoto T, Kondo S, Suzuki H. Inhibition of tumor growth and metastasis by an immunoneutralizing monoclonal antibody to human vascular endothelial growth factor/vascular permeability factor121. Cancer Res 1995;55:5296-301.
250 D'Angelo G, Struman I, Martial J, Weiner RI. Activation of mitogenactivated protein kinases by vascular endothelial growth factor and basic fibroblast growth factor in capillary endothelial cells is inhibited by the antiangiogenic factor $16-\mathrm{kDa}$ N-terminal fragment of prolactin. Proc Natl

$251 \mathrm{Hu}$ DE, Fan TP. Suppression of VEGF-induced angiogenesis by the protein tyrosine kinase inhibitor, lavendustin A. Br F Pharmacol 1995;114:2628 .

252 Seymour LW, Shoaibi MA, Martin A, Ahmed A, Elvin P, Kerr DJ, et al. Vascular endothelial growth factor stimulates protein kinase c-dependent phospholipase d activity in endothelial cells. Lab Invest 1996;75:427-37.

253 Xia P, Aiello LP, Ishii H, Jiang ZY, Park DJ, Robinson GS, et al. Characterization of vascular endothelial growth factors effect on the activation of protein kinase $\mathrm{C}$, its isoforms, and endothelial cell growth 7 Clin Invest 1996;98:2018-26.

254 Hammes H-P, Brownlee M, Jonczyk A, Sutter A, Preissner KT. Subcutaneous injection of a cyclic peptide antagonist of vitronectin receptor-type integrins inhibits retinal neovascularisation. Nature Med 1996;2:529-33.

255 Ashton P, Blandford DL, Pearson PA, Jaffe GJ, Martin DF, Nussenblatt RB. Review: implants. F Ocul Pharmacol 1994;10:691-701.

256 Cheng CK, Berger AS, Pearson PA, Ashton P, Jaffe GJ. Intravitreal sustained-release dexamethasone device in the treatment of experimental uveitis. Invest Ophthalmol Vis Sci 1995;36:442-53.

257 Hashizoe M, Ogura Y, Kimura H, Moritera T, Honda Y, Kyo M, et al. Scleral plug of biodegradable polymers for controlled drug release in the vitreous. Arch Ophthalmol 1994;112:1380-4. 